\title{
Reconciling Vision with Reality Réconcilier la vision et la réalité
}

\author{
Kananaskis Country, Alberta \\ October 15-19, 1989 \\ le $15-19$ octobre, 1989
}

The Forestry Chonicle

Volume 65, Number 6, December 1989

Annual Meeting Supplement

\section{President's Report 1988-89}

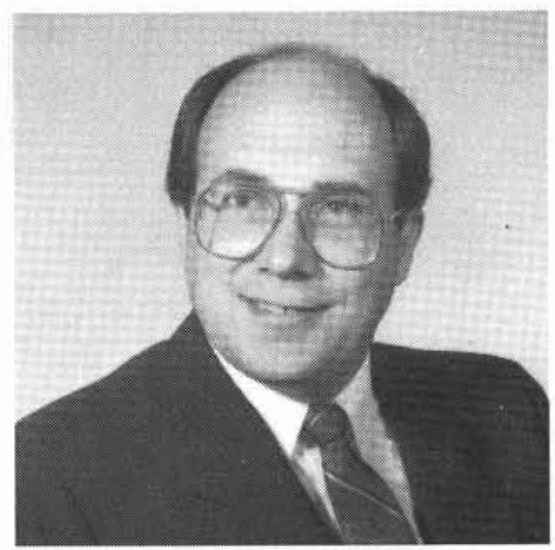

This has been an exciting year. When I decided some years ago to become involved in the Executive Committee of the CIF/IFC, the objective of promoting better forest land management in Canada, increasing the awareness and decision-makers and the public about forestry, and raising the profile of CIF/IFC amongst the forestry constituency were present but the ways to reach them were vague in my mind.

As I write this President's Report, I feel it is as much a report to the recent presidents of the CIF/IFC as to the membership at large. Indeed, I am much indebted to the recent Presidents and especially those with whom I worked on the Executive Committee (Toovey, Carrow, Kayll). They laid the ground work for many of the successes of this past year. In my turn, I hope that I have helped prepare for the future.

One thing that makes me uneasy with this title of President's Report, is that it seems to imply that it is a report on what the President alone has done. Nothing is further from the truth because the support of the Executive Director, the Executive Committee, the Chairmen of the Working Groups, the Executives of Sections and basically all the members is essential to the successful conduct of the CIF/IFC. The existence of a Strategic Plan adopted by the membership has also been of great help. Knowing what was the clear consensus of the membership, I could put my efforts in getting things done and in moving ahead.

On internal matters of the CIF/IFC, the year has been quite active:
The Forestry Chronicle

Volume 64, Numéro 6, decembre 1989

Supplément de l'Assemblée Annuelle

\section{Rapport du président du CIF/IFC 1988-89}

Quelle année: Lorsque j'ai décidé, il y a quelques années de m'impliquer dans le Comité exécutif du CIF/IFC, les objectifs de la promotion d'un meilleur aménagement des terres forestières au Canada, l'accroissement de la sensibilisation des preneurs de décisions et du public relativement à la foresterie, et l'accroissement de la présence du CIF/IFC au sein du Forum forestier étaient d'actualité, mais les moyens de les atteindre étaient vagues dans mon esprit.

J'ai l'impression en rédigeant le rapport du Président, qu'il s'agit autant d'un rapport à l'attention des tout derniers présidents du CIF/IFC que pour les membres en général. Je suis en effet très reconnaissant envers les derniers présidents, spécialement ceux avec qui j'ai siégé au Comité exécutif (Toovey, Carrow, Kayll) et qui ont ébauché la plupart des succès de l'année. En contrepartie, j'espère avoir préparé l'avenir.

L'une des choses qui me cause un peu de problème, est le titre du rapport du Président: cela semble sous-entendre qu'il s'agit d'un rapport sur ce que le président lui-même a réalisé. Cela est tout le contraire, car l'appui du directeur exécutif, du Comité exécutif, des directeurs des Groupes de travail, des responsables de section et ainsi que de tous les membres est essentiel à la bonne marche du CIF/IFC. L'existence même du plan stratégique adopté par les membres a été aussi d'un grand secours. Cela me permettait de savoir quels étaient précisement les consensus exprimés par les membres, et de consacrer mes efforts à tendre vers les objectifs et à faire progresser les choses.

L'année écoulée a été fébrile au sein du CIF/IFC:

- Même si j'avais prévu de visiter plus de sections, les réunions auxquelles j'ai participées m'ont permis de rencontrer les deux tiers des membres.

- Quatre de nos six brochures ont été révisées, et nous avons tenté d'améliorer nos communications avec les Sections et les Groupes de travail.

- Grace à la participation soutenue de Brian Haddon et des présidents des Groupes de travail, nous avons connu beaucoup plus de résultats que par les années passées.

- Nous avons pu accroître le nombre de membres actifs, tout en étant particulièrement heureux d'accroître le nombre de nos membres corporatifs. Peut-être s'agit-il d'une marque de reconnaissance pour les réalisations de I'IFC.

- Malgré le niveau sans cesse croissant d'activité et de participation du CIF/IFC, l'efficacité des employés de l'Institut 
- Although I would have liked to have visited more sections, those meetings I attended represented $2 / 3$ of the members.

- Four out of six brochures have been revised and we tried to streamline communications with Sections and Working Groups. Through involvement of Brian Haddon and Working Group Chairmen, there was much more action on this effort than in recent years.

- We managed to increase the number of active members, but were especially successful in attracting new sustaining membership. Maybe this is a recognition of the work that is done by the CIF.

- In spite of ever increasing activity and involvement of the CIF/IFC, the quality of the Institute's employees at Head Office permitted us to change printers for the Forestry Chronicle, negotiate with a new Production Manager and end with a healthy surplus that allowed us to reduce our cummulative defict and we didn't need to sacrifice the quality of the Chronicle in our initiatives.

As far as the objectives of the Institute are concerned, I think that the past year has been a milestone. To promote better forest management, the key actions have been:

- Letters to the Prime Minister of Canada, Opposition parties' leaders, and the Premiers of the Provinces demanding the renewal of the FRDA's, acknowledging the wide support of the Forestry Constituency, which was stimulated into this initiative by the CIF/IFC.

- Letters to the Minister of Agriculture on pesticide use in forestry and CIF/IFC representation on the forestry pesticide caucus.

- Letter to the Environment Minister and officials stressing the importance of forestry representatives on sustainable development round tables.

- Letters to and contact with the Minister and officials of Forestry Canada, opposition parties and Standing Committee members on the proposed federal Forestry Act.

- Six Forestry Dialogues were sent to all MP's in Ottawa and 17 of them attended a CIF/IFC reception (a three-fold increase over last year).

- A letter to the CCFM expressing our support and our views on the essential follow-up and implementation of the National Forest Sector Stretegy for Canada and the recommendations of the R\&D Forum in Edmonton.

In addition to our contacts, with Ministers and MPs mentioned above, the following initiatives were taken to raise the forestry awareness of decision makers and the public.

- Meetings with the federal Minister responsible for forestry and with three other provincial ministers. We also met with the Chairman of the Canadian Council of Forest Ministers. au siège social nous a permis de changer d'imprimeurs pour le Forestry Chronicle, d'embaucher un nouveau directeur de la production, et de terminer l'année avec un bon surplus qui nous a permis de réduire notre déficit accumulé, et cela sans avoir à sacrifier sur la qualité du Chronicle.

Mais en autant que les objectifs de I'Institut sont concernés, je crois que la dernière année en a été une décisive. Dans le but de promouvoir un meilleur aménagement, les gestes suivant ont été entrepris:

- Des lettres au Premier Ministre, au chef des partis de l'opposition, et aux Premiers Ministres des provinces leur demandant le renouvellement des ententes fédéralesprovinciales de mise en valeur de la ressource forestière, et d'apporter un soutien étendu au Forum forestier, une initiative qui a été mise en place par le CIF/IFC.

- Des lettres au Ministre de l'Agriculture sur l'utilisation des pesticides en foresterie et la représentation du CIF/FFC au sein du caucus sur les pesticides forestiers.

- Des lettres au Ministre ainsi qu'aux gestionnaires du ministère de l'Environnement leurs soulignant l'importance de la représentation forestière de l'Environnement leurs soulignant l'importance de la représentation forestière aux tables rondes sur le rendement soutenu.

- Des lettres et des rencontres avec le Ministre et les gestionnaires de Forêts Canada, avec les partis de l'opposition et les membres du Comité permanent au sujet du projet de Loi fédérale sur les Forêts.

- Six Dialogues Forestiers ont été acheminés à tous les députés fédéraux à Ottawa et 17 d'entre eux participèrent à une réception du CIF/IFC (trois fois plus que l'an dernier pour ce dernier point).

- Nous avons écrit au CCMF pour exprimer notre support et nos opinions en ce qui a trait à l'essentiel du suivi et des réalisations de la Stratégie nationale du secteur forestier du Canada, ainsi que nos recommandations suite au Forum sur la R\&D tenu à Edmonton.

De façon à accroître la sensibilisation des preneurs de décisions et du public au sujet de la foresterie au Canada, en plus des rencontres avec les Ministres et les députés fédéraux mentionnées ci-dessus, les principales initiatives ont été:

- Des rencontres avec le Ministre fédéral responsable des forêts ainsi qu'avec trois ministres provinciaux. Nous avons aussi rencontré le Président du Conseil canadien des Ministres des Forêts.

- La tenue du premier Forum des communicateurs forestiers organisé par le CIF/IFC, commandité par Forêts Canada et ayant eu des représentants des plus importants organismes forestiers sur le comité de direction. Le succès de ce forum a été reconnu par tous les participants. Un second forum est déjà au stade des préparatifs.

- Des discussions fructeuses avec l'ACPPP de façon à accroîtra les liens entre les deux organismes. Ceci accrốtra la présence et l'image du CIF/IFC au sein de l'industrie.

Dans le domaine des progrès en science forestière et de la formation des professionnels forestiers, les principaux événements ont été:

- La tenue d'un symposium réunissant et les gestionnaires et les chercheurs à Petawawa et la préparation d'un second pour 1990. A ce jour, nous espérons que tous les exposés seront publiés soit dans le J.C.R.F., soit dans le Forestry Chronicle.

- La nomination d'un représentant de I'IFC sur le Comité consultatif de la recherche forestière au Canada.

- L'accord par toutes les parties impliquées sur un Enoncé de politique pour le Comité d'équivalences forestières du 
- Holding of the first Forestry Communicators Forum organized by the CIF/IFC, sponsored by Forestry Canada and with representatives of key forestry agencies in the steering committee. It was a success acknowledged by all participants. A second one is already in the planning stage.

- Fruitful discussion with CPPA to increase linkages between our organizations. This will raise the profile of the CIF/IFC in industrial circles.

In the advancement of forest science and training of forestry professionals, the main events were:

- Holding a symposium catering to both managers and scientists at Petawawa and arranging for a second one in 1990. We hope that all papers will be published either in the CJFR or in the Forestry Chronicle.

- Designation of a CIF representative on the Forest Research Advisory Council of Canada.

- Acceptance by all agencies involved of a Policy Statement for the Canadian Forestry Accreditation Board and planning for the first accreditation visit.

I won't go further because the details are not the key element. All that I want to convey to you is the feeling that the Institute is well and alive, actively involved in issues and increasingly recognized in professional, industry and government circles. The CIF/IFC needs your support to continue to go further.

As I said at the beginning, this is not due to my actions alone. Without excluding anybody, however, let me single out J.H. Cayford, Denise Trepanier and Burla Cayford as well as other Executive Committee members. I thank them. I also take this opportunity to thank my previous employer, the Ministere de l'Energie et des Resources du Quebec, who, through the support and collaboration I received from its officials like Gilbert Paillé, made my holding the Presidency possible.

If I have a suggestion for next year, it would be: Let's keep up the good work! The need to put forestry forward is great and if professionals active in forestry don't get involved, who will?
Canada et la planification de la première visite d'évaluation.

Je n'apporterai pas plus de détails car ceux-ci ne sont pas les éléments-clés. Ce que je veux vous laisser comme message, est que l'Institut est très actif, impliqué de près dans les sujets d'actualité et de plus en plus reconnu dans les cercles professionnels, industriels et gouvernementaux. Le CIF/IFC a besoin de votre support afin d'aller de l'avant et de progresser. Vous en serez que plus fier.

Comme je l'ai mentionné au début de ce rapport, tout ceci n'est pas le fruit de mes seuls efforts. Sans vouloir oublier quiconque, laissez-moi toutefois souligner le travail de J.H. Cayford, de Denise Trepanier et de Burla Cayford, ainsi de tous les membres du Comité exécutif. Je les remercie. J'aimerais aussi profiter de l'occasion pour remercier mon ancien employeur, le Ministère de l'Energie et des Ressources du Québec, qui, grâce au support et à la collaboration que j'ai reçus des gestionnaires seniors tel Gilbert Paillé, a rendu ma participation possible en tant que Président.

Si j'avais une suggestion à formuler pour l'an prochain, ce serait: Poursuivons notre bon travail! La nécessité de mettre la foresterie de l'avant est grande et si les professionnels actifs en foresterie ne s'impliquent pas, qui le fera?

Claude Godbout

\section{The Executive Directors Report, 1988-89}

This report is for my first full year as Executive Director. It was a successful year - the total membership figure remained constant, but included substantially fewer members of the Alberta Registered Professional Foresters Association who had not officially joined the Institute, the long-term Institute deficit was reduced by $\$ 7138$., a Strategic Plan was issued, the policy brochure "How Should Canada's Forests be Managed" was revised and republished, the Annual Meeting was highly successful and two successful symposia were organized - one on research and the other on forestry communications.

More detail on the operations of the Institute is provided in the following three sections entitled administration, projects and communications and liaison.

\section{Administration}

In 1988-89 revenues exceeded expenditures by $\$ 7138$., and our deficit was reduced from \$19195. to \$12 057. However, our financial situation remains tight. Next year we shall be faced with costs for our involvement in the national forestry accreditation project and in 1990-91 by the replacement of the Executive Director. By then I expect a need for three full-time staff members. During the past year, $70 \%$ of our revenues was obtained from members dues; the remaining $30 \%$ was from Forestry Chronicle subscriptions, page charges, sale of reprints and advertising. Minor revenues were realized through provision of mailing services and organization of the forestry communicators' forum. During the same period expenditure percentages were as follows: 
salaries and benefits $30 \%$; rent $7 \%$; office supplies and operations $16 \%$; travel $12 \%$; rings and awards $5 \%$ and Forestry Chronicle $30 \%$. Expenditures have increased by only $2 \%$ since 1986-87.

Forestry Chronicle operations are outlined by the Editor and the Production Manager. The net cost of the journal in 1988-89 was approximately $\$ 11000$., as compared with $\$ 15000$ in $1987-88$ and $\$ 9700$ in 1986-87. During the year a new printing contract was negotiated with Love Printing Ltd.; they printed the June 1989 issue. I also assisted in the selection of a new production Manager for 1991. Special features published during the year were the report of the Forest Research Advisory Council of Canada, August, a listing of Universities and Schools offering Forest Sector-related programs, August, the Annual Meeting Report, December, CIF/IFC Strategic Plan - 1989, April, Report of Forestry Communicators' Forum, June, and CIF Policy Statement, How Should Canada's Forests be Managed?, June.

The awards program continued during the year. A total of 245 rings were presented to graduates from six universities. Other awards included six Gold Medals, the three achievement awards and one special award. Eight members were admitted to the Golden Year Club.

The 1988 Annual Meeting held in Prince Albert, Saskatchewan, was very successful with the theme "Forest Management - A Shared Responsibility". Total registration was 277 of whom 152 were full delegates. Financially, there was a surplus of $\$ 6200$.

The 1989 Annual Meeting is being hosted by the Rocky Mountain Section in Kananaskis Country, Alberta, October 15-19, 1989. The theme is "Reconciling Vision with Reality"; the Annual Meeting Chairman is Chuck Geale. The 1990 meeting will be held in Fredericton and the 1991 meeting in Toronto.

Since the 1988 Annual Meeting, the Executive Committee has met six times; two were teleconferences. Meetings were held in Prince Albert, September 22; Vancouver and Victoria, January 18-19; Toronto, March 7-8; and Ottawa, May 10-11. The Executive Director is responsible for agenda preparation, recording of minutes and follow-up action.

Forestry Update/Information Forestier was issued monthly; its distribution was extended to include members of the forest constituency and the forestry universities. During the year the policy statement on How should Canada's Forests be Managed? was revised by the Forest Science and Technology Board (FSTB). The statement was issued as a separate and was published in The Forestry Chronicle. Statements on forest pesticides, acid rain and the CIF/IFC are currently being up-dated, the first two by the FSTB and the third by the Executive Director.

Various administrative functions concerning memberships, dues, The Forestry Chronicle, miscellaneous correspondence and resolutions continued throughout the year. The Section Officer's Manual was updated and will be distributed to all Sections during the summer of 1989.

\section{Project Officer}

The major initiatives were undertaken by the Institute during the year, all of which required input from the Executive Director. The first was the preparation of the Strategic Plan - 1989. Following the discussion at the Annual Meeting, I revised the document and arranged for its publication.
The second initiative was the organizaiton, collaboratively with Forestry Canada, of a symposium entitled "Advances in Canadian Forestry Research", which was held at the Petawawa National Forestry Institute, October 3-4, 1988. About 100 attended the symposium which was organized by the Algonquin Section; papers are to be published in the Canadian Journal of Forest Research. The Central Ontario Section will host a second symposium in 1990. The Executive Director provided liaison between the Organizing Committee and the Executive Committee and participated in selected meetings of the Organizing Committee.

The third initiative was the organization of the Forestry Communicators' Forum held in Toronto, March 8-9, 1989. The Forum was organized for Forestry Canada and in cooperation with the Canadian Forestry Association, Canadian Pulp and Paper Association, Council of Forest Industries of B.C. and the Canadian Council of Forest Ministers. The meeting was chaired by Dave Fayle, and I was secretary. A report on the meeting was published in the June issue of The Forestry Chronicle.

I continued to coordinate the preparation and distribution of Forestry Dialogue Forestier and the Institute's newsletter for federal parliamentarians. Each issue is now published in The Forestry Chronicle. Issues produced in the last year are as follows:

18. Forestry Associations (September)

19. Canadian Forest Facts (March)

20. One Billion Dollars for Forest Management at Stake (April)

21. Acid Rain, Air Pollution and Hardwood Forests (June)

22. Forest Sector Dependent Communities in Canada (July)

At the 1988 Annual Meeting a resolution was passed that called for a review of past Annual meetings with a view towards recommending means to improve the overall meeting structure and organization. I served as Secretary of a Task Force involving J.A. Benson, C. Geale, B. Haddon and J.A. Munro. A report has been prepared for discussion at the Annual Meeting.

During the year I have written several articles for The Forestry Chronicle on such topics as the Forest Research Advisory Council of Canada report, Sault Ste Marie - Forestry Capital of Canada 1990, Auditor General's Report on Forestry, Resolutions 1988 Annual Meeting. Forestry Canada Estimates and the President's Reception.

Other initiatives included the coordination of CIF/IFC participation in the National Capital Development Program for Confederation Blvd. Fourteen sections - Pacific, Vancouver Island, Vancouver, Cariboo, Rocky Mountain, Northwestern Ontario, Central Ontario, Algonquin, Southern Ontario, Ottawa Valley, Champlain, Orleans, Nova Scotia and Newfoundland were involved in the sponsorship of six shade trees along the boulevard.

During the year, the Canadian Forestry Accreditation Board (CFAB) was established by the Canadian Federation of Professional Forester's Associations with A.J. Kayll named as CIF/IFC member and C.H. Gairns as alternate. Head Office continued to manage the financial aspects of the study carried out by V.J. Nordin to develop the proposal for national accreditation. 


\section{Communications and Liaison}

Communication and liaison both internally within the CIF/IFC and with external agencies is an important role of the Executive Director as the Institute endeavours to strengthen its national leadership role.

Internally I maintain regular contact with members of the Executive Committee and with Sections. Mailings are made weekly to Executive Committee members and monthly to Sections. During the year I have met with 11 of our Sections; Maritimes, Orleans, Champlain, Ottawa Valley, Algonquin, Northwestern Ontario, Southern Ontario, Central Ontario, Rocky Mountain, Vancouver and Vancouver Island.

With the Executive Commmittee I have met with the Minister of State (Forestry), F. Oberle and with his predecessor, the Hon. St. Germain. I have also met with officials of Mr. Oberle's staff, senior officials of Forestry Canada, the Canadian International Development Agency and the International Development Research Centre. Contact has also maintained with the forestry critics of the two opposition parties and with members of the media.

I continue to serve as a member of the Executive Board of the International Union of Forestry Research Organizations (IUFRO) and as Chairman of its Administration and Nominating Committees. I attended the Board meeting in Oregon in September 1988 and in May visited the Secretariat and the Treasurer in Vienna and Zurich respectively. I am also a member of the Steering, Excursion and Scientist Assistance Committees for the 1990 IUFRO World Congress, Montreal. I am involved with the Forest Science and Technology Board in the development of two special issues of The Forestry Chronicle in conjunction with the Congress.

Contact has also been maintained with the provincial Registered Professional Associations, Canadian Forestry Association, Woodlands Section of the Canadian Pulp and Paper Association, Canadian Standards Association, Wildlife Habitat Canada, Canadian Lumbermen's Association and Canadian Wood Council.

In closing I wish to thank Denise Trepanier, our Office Manager, and my wife Burla, Clerk, for their service, the Executive Committee, and all members who have contributed towards the objectives of the Institute.

J.H. Cayford, R.P.F. August 9, 1989

\section{Editor's Report}

The Forestry Chronicle is primarily a professional periodical whose contents should reflect the interests and needs of the CIF members. Its editorial policy, which has changed little for some years, is as follows.

The Chronicle will publish scientific and technical papers, which will receive peer reviews from at least two anonymous outside reviewers. These papers, however, should be aimed at the practicing forester or resource manager, not at the professional researcher. It will also publish professional papers, and the proceedings of symposia or workshops relating to forestry. Professional papers may cover case histories in forest management, current forestry issues, forest history and so on. They may be more speculative and argumentative than scientific papers, but will not usually include research results and will usually be reviewed only by the editor and one of the associate editors.

The Chronicle also makes a practice of publishing important policy documents or reports dealing with forestry. The June ' 89 issue, for example, contains the highlights of sixvolume study commissioned by Forestry Canada entitled "'Canada's Forest Industry. The Next Twenty years: Prospects and Priorities". It also includes the CIF's own policy statement "How Should Canada's Forests be Managed?" and the April issue contained the CIF Strategic Plan. It is also our practice now to publish copies of Forestry Dialogue Forestier, the information leaflet prepared by the CIF for Members of parliament.

Table I shows a comparison of the contents of The Forestry Chronicle for 1987, 1988 and the first three issues of 1989. The number of papers being submitted for publication has gradually increased from 45 in 1983 to 76 in 1988, and the length of each volume has increased by two-thirds during the same period. The actual length of each volume depends considerably on how many pages are devoted to the proceedings of symposia, workshops and so on. Volume 66 (1990) should be a bumper one. Not only will it include the proceedings of a symposium on site quality, but in anticipation of the 19th World IUFRO Congress in Montreal (August $5-11)$ special issues will be devoted to international forestry and advances in forestry research.
Table 1. Comparison of the contents of The Forestry Chronicle for 1987,1988 and 1989

\begin{tabular}{|c|c|c|c|}
\hline & 1987 & 1988 & 1989 1] \\
\hline Total pages & 504 & 540 & 245 \\
\hline Pages of scientific and & & $143(25)$ & $50(9)$ \\
\hline $\begin{array}{l}\text { technical articles } 2 \text { f } \\
\text { Pages of professional articles } 2 \text { / }\end{array}$ & $\begin{array}{l}133(26) \\
100(26)\end{array}$ & $\begin{array}{r}143(25) \\
83(20)\end{array}$ & $\begin{array}{l}50(9) \\
60(17)\end{array}$ \\
\hline $\begin{array}{l}\text { Pages of symposia or } \\
\text { workshops } 21\end{array}$ & $46(5)$ & $63(18)$ & $10(2)$ \\
\hline $\begin{array}{l}\text { Pages or major policy } \\
\text { statements or reports } 3 \text { ] }\end{array}$ & - & $17(3)$ & $20(3)$ \\
\hline Pages of other material & 225 & 234 & 105 \\
\hline No. of articles submitted & 70 & 76 & 33 \\
\hline No. of articles under review & 55 & 60 & 57 \\
\hline No. of articles rejected & 15 & 12 & 8 \\
\hline
\end{tabular}

1/ Data for first three issues only.

2) Figures in brackets are no. of articles published.

3/ Not compiled for 1987

The Chronicle could undoubtedly be improved without great additional cost. For example, coverage of forest policy developments and forestry issues across Canada is sporadic because news of them reaches me on a hit or miss basis. The sections and individual members could help greatly in this respect by keeping the editor better briefed on such developments. Similarly, I write most of the editorials, not because I wish to but because few others are willing to volunteer. Have you a topic on which you would like to vent your prejudices? If so, write an editorial - but a good one.

In conclusion, I wish to thank the associate editors and reviewers for their unselfish efforts on behalf of The Forestry Chronicle. In particular I wish to thank for their help Paul E. Vezina, Chris Yeatman and Marcien Roberge who resigned as associate editors, during the year owing to sickness, overseas posting and retirement respectively.

I.C.M. Place July 24, 1989 


\section{Production Manager's Report}

This report covers production of The Forestry Chronicle for the fiscal year 1988-1989 and, therefore, deals with the publication of the last three issues of Volume 64 and the first three of Volume 65.

Table 1 compares the contents of our publication for the last four fiscal years 1985/86, 1986/87, 1987/88, and 1988/89. Attention is drawn to the increased proportion of professional articles, which exceed the number of scientific and technical articles, for the first time in recent years, in 1988/89. During the last fiscal year the material in the magazine was reorganized to place professional articles in each issue before the scientific and technical articles.

During the year the Institute invited several printers in the Ottawa area to submit competitive tenders for printing The
Table 1. Comparison of the contents of The Forestry Chronicle for Fiscal Years 1985/86, 1986/87, 1987/88 and 1988/89.

\begin{tabular}{|c|c|c|c|c|}
\hline$=$ & $1985 / 86$ & $1986 / 87$ & $1987 / 88$ & $1988 / 89$ \\
\hline No. of professional articles & 18 & 17 & 24 & 29 \\
\hline Pages of professional articles & 89 & 75 & 96 & 116 \\
\hline $\begin{array}{l}\text { No. of scientific and technical } \\
\text { articles } \\
\text { Pages of scientific and }\end{array}$ & 27 & 35 & 32 & 20 \\
\hline technical articles & 134 & 186 & 171 & 121 \\
\hline Pages devoted to symposia & 48 & 114 & 64 & 0 \\
\hline Pages of other material & 235 & 223 & 245 & 251 \\
\hline Total pages & 506 & 598 & 576 & 488 \\
\hline
\end{tabular}

Table 2. Publishing schedule for The Forestry Chronicle, Fiscal Year 1988/89.

\begin{tabular}{|c|c|c|c|c|c|c|}
\hline & Aug. & Oct. & Dec & Feb & Apr. & June \\
\hline Paste-up to printer & Aug 2 & Oct 11 & Nov 17 & $\operatorname{Jan} 19$ & Mar 22 & May 29 \\
\hline Page proof received & Aug 11 & Oct 17 & Nov 29 & Jan 27 & Apr 3 & June 6 \\
\hline Corrected page proof returned & Aug 11 & Oct 17 & Nov 29 & Jan 27 & Apr 3 & June 6 \\
\hline Blueprint received & Aug 15 & Oct 19 & Dec 5 & Feb 2 & Apr 10 & June 13 \\
\hline Blueprint returned & Aug 15 & Oct 19 & Dec 6 & Feb 2 & Apr 10 & June 13 \\
\hline Chronicle delivered to CIF/IFC & Aug 17 & Oct 31 & Dec 14 & Feb 9 & Apr 21 & June 16 \\
\hline Chronicle mailed & Aug 22 & Nov 3 & Dec 22 & Feb 15 & Apr 25 & June 20 \\
\hline
\end{tabular}

Forestry Chronicle. This resulted in a change, effective with the June 1989 issue. Printing is now being done by Love Printing Services Itd.

Producing and mailing a publication of this nature on schedule requires vigorous observance of the cut-off date for receiving new material (15th day of the month prior to publication) and careful attention by the printer to delivering galleys, page proofs, blueprints and the publication without delays. Table 2 shows how well schedules were met during the last fiscal year. There were no delays.
This is the last year that I shall be reporting as Production Manager of The Forestry Chronicle and I wish to express my sincere appreciation to the Editor, The Executive of the Institute and to the Head Office Staff, especially the Office Manager, Denise Trepanier, for forbearance and assistance during the last four years.

D.R. Redmond

\section{Report of the Finance Committee - 1988-89}

\section{Highlights of the 1988-89 Fiscal Year}

The Finance Committee consisted of Jim Marshall, Bob Bourchier, Jim Cayford and myself. We met five times - after the quarterly financial statement and before an Executive Committee meeting.

Table 1 shows our current financial position relative to the 1988-89 budget and the proposed budget for 1989-90. Membership is the key to our revenues. Currently it is 2347 compared with 2350 in 1987-88 - down only slightly. Obviously we need more members, although the $5 \%$ increase in dues in 1989-90 should keep us solvent. The biggest variance in income from the budget was in miscellaneous revenues, which usually come from a variety of sources. In general, however, the actual revenues were fairly close to those estimated.

Expenses were roughly $\$ 6000$ less than those estimated, owing largely to reductions in travel costs and postage. Travel costs fell because of the location of meetings and greater support to the directors by their employers. We also collect a small fee for mailings on behalf of Forestry
Canada and other agencies. The Forestry Chronicle cost more than estimated because of general increases in costs and the absence of symposia proceedings during the fiscal year. CIF deficit, however, is down by a healthy $\$ 7138$, bringing it to $\$ 12057$.

\section{Proposed Budget for 1989-90}

Increasing membership is an on-going objective and Chronicle advertising offers a challenge for more revenue. The cost of the Chronicle is expected to fall because of lower printing costs, with the new printer. Office expenses will increase somewhat because of the new FAX system and extra photocopying. Telephone costs will include teleconference charges, which help to reduce travel costs. Ring cost will rise because of increasing numbers of forestry graduates. The National Accreditation program will require at least $\$ 4000$. However, the CIF should show a surplus of about $\$ 3000$.

Many thanks to the other Committee members and Jim Cayford and his staff. 
Table 1. Comparison of the 1988-89 Budget, Revenue and Expenses, and Draft 1989-90 Budget.

\begin{tabular}{|c|c|c|c|c|}
\hline & $\begin{array}{l}\text { Budget } \\
1988-89\end{array}$ & $\begin{array}{c}\text { Actual } \\
1988-89\end{array}$ & Variance & $\begin{array}{c}\text { Draft Budget } \\
1989-90\end{array}$ \\
\hline \multicolumn{5}{|l|}{ Revenues } \\
\hline Members dues & 185200 & 185215 & 15 & 194500 \\
\hline Chronicle subscriptions & 30000 & 30770 & 770 & 29000 \\
\hline Chronicle advertising & 18000 & 16063 & -1937 & 16000 \\
\hline Chronicle reprints & 8000 & 10820 & 2820 & 14000 \\
\hline Chronicle page charges & 15000 & 15945 & 945 & 16000 \\
\hline Interest income & 2000 & 4586 & 2586 & 4000 \\
\hline Imperial life commission & 2000 & 1043 & -957 & 2500 \\
\hline Annual Meeting & 3000 & 3129 & 129 & 3000 \\
\hline Miscellaneous & 3400 & 133 & -3267 & 1000 \\
\hline Total revenue & 266600 & 267704 & 1104 & 280000 \\
\hline \multicolumn{5}{|l|}{ Expenses } \\
\hline Salaries and benefits & 70000 & 69018 & -982 & 72000 \\
\hline Part-time help & 9000 & 9037 & 37 & 9500 \\
\hline Office expenses & 7500 & 7249 & -251 & 11000 \\
\hline Office supplies & 3500 & 3336 & -164 & 5000 \\
\hline Rent & 18000 & 18539 & 539 & 19000 \\
\hline Postage & 9000 & 6986 & -2014 & 8000 \\
\hline Telephone & 8000 & 5264 & -2736 & 6500 \\
\hline Travel, executive & 14000 & 12983 & -1017 & 12000 \\
\hline Travel, Executive Director & 9000 & 5828 & -3172 & 9000 \\
\hline Travel, directors & 9000 & 5652 & -3348 & 8500 \\
\hline Accounting \& audit & 2000 & 2354 & 354 & 2500 \\
\hline Hospitality & 1000 & 1915 & 915 & 2000 \\
\hline Translation & 3000 & 2108 & -892 & 3000 \\
\hline Forestry Chronicle & 74100 & 84542 & 10442 & 80000 \\
\hline Annual Meeting & 5000 & 9272 & 4272 & 5000 \\
\hline Medals, rings, awards ${ }^{2}$ & 14500 & 10281 & 4219 & 12000 \\
\hline Miscellaneous ${ }^{3}$ & 10000 & 6202 & -3798 & 8000 \\
\hline National accreditation & - & - & - & 4000 \\
\hline Total expenses & 266600 & 260566 & -6034 & 277000 \\
\hline Excess revenue over expenses & 0 & 7138 & & 3000 \\
\hline
\end{tabular}

\section{Notes}

(1) Miscellaneous

Service to Sections 300

Rings and jewellery 2000

Novelty items $\quad 1000$

Sundry 100

Total 3400

(2) Medals, Rings, Awards

Rings and jewellery $\quad 7249$

Medals \& awards $\quad 1655$

Novelty items 559

$\begin{array}{ll}\text { Certificates } & 818\end{array}$

Total

10281
(3) Miscellaneous

Bank charges 418

Subscriptions \& membership $\quad 630$

Printing 3044

$\begin{array}{ll}\text { Sundry } & 2110\end{array}$

Total

6202

Mark Schaefer, R.P.F. Chairman

\section{Auditors' Report}

We have examined the balance sheet of the Canadian Institute of Forestry - Institut Forestier du Canada as at June 30,1989 , and the statement of operations and deficit for the year then ended. Our examination was made in accordance with generally accepted auditing standards, and accordingly included such tests and other procedures as we considered necessary in the circumstances.
In our opinion, these financial statements present fairly the financial position of the Institute as at June 30,1989 , and the results of its operations for the year then ended in accordance with generally accepted accounting principles applied on a basis consistent with that of the preceding year.

OTTAWA, August 15, 1989

Cook, Perry, Sewell \& Co. Chartered Accountants 
Balance Sheet - June 30, 1989

\section{ASSETS}

1989

1988

Current Assets

Cash in bank

Accrued interest receivable

Accounts receivable

\begin{tabular}{rr}
$\$ 114954$ & $\$ 65681$ \\
449 & 348 \\
11425 & 19150 \\
\hline 126828 & 85179
\end{tabular}

Fixed Assets

Office furniture and equipment

$\underline{\underline{\$ 126829} \quad \frac{1}{\$ 85180}}$

\section{LIABILITIES AND CAPITAL DEFICIENCY}

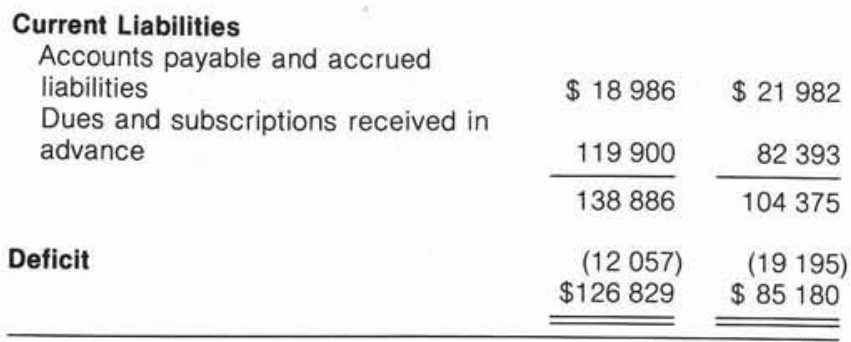

Schedule of Forestry Chronicle Revenues and Expenditures for the Year Ended June 30, 1989

\begin{tabular}{|c|c|c|}
\hline & 1989 & 1988 \\
\hline \multicolumn{3}{|l|}{ Revenues } \\
\hline Advertising & $\$ 16063$ & $\$ 13732$ \\
\hline Page charges & 15945 & 17698 \\
\hline Reprints & 10820 & 11435 \\
\hline \multirow[t]{2}{*}{ Subscriptions and sales } & 30770 & 28562 \\
\hline & $\$ 73598$ & $\$ 71427$ \\
\hline \multicolumn{3}{|l|}{ Expenditures } \\
\hline Editor's honorarium & $\$ 3215$ & $\$ 4385$ \\
\hline Mailing & 8855 & 8057 \\
\hline Printing & 59059 & 60420 \\
\hline Production & 6110 & 5883 \\
\hline Reprints & 6260 & 4485 \\
\hline \multirow[t]{2}{*}{ Miscellaneous } & 1043 & 3375 \\
\hline & $\$ 84542$ & $\$ 86605$ \\
\hline Net cost of operating & & \\
\hline The Forestry Chronicle & $\$ 10944$ & $\$ 15178$ \\
\hline
\end{tabular}

Statement of Operations and Deficit for the Year Ended June 30,1989

1989

1988

Revenues

Annual meeting

Forestry Chronicle (per schedule)

Group insurance commission

Interest on investments

Members' dues

Miscellaneous

\begin{tabular}{rrr}
$\$ 3129$ & $\$ 798$ \\
73598 & 71427 \\
1043 & 2139 \\
4586 & & 3090 \\
185215 & & 180570 \\
133 & & 932 \\
\cline { 3 - 3 } 267704 & & 258956 \\
\hline
\end{tabular}

\section{Expenditures}

\author{
Administration \\ Annual Meeting \\ Hospitality \\ Legal and audit \\ Medals, caps, rings and awards \\ Miscellaneous expense \\ Office expenses \\ Office supplies \\ Postage \\ Rent and hydro \\ Telephone \\ Translation
}
Forestry Chronicle (per schedule)
Travel
Directors
Executive
Executive-Director

\section{Total expenditures -} carried forward

\begin{tabular}{|c|c|}
\hline 9272 & 4826 \\
\hline 1915 & 1303 \\
\hline 2354 & 2096 \\
\hline 10281 & 9484 \\
\hline 6202 & 19415 \\
\hline 7249 & 7823 \\
\hline 3336 & 2642 \\
\hline 6986 & 6286 \\
\hline 18539 & 18062 \\
\hline 5264 & 3624 \\
\hline & \\
\hline 73506 & 76814 \\
\hline 84542 & 86605 \\
\hline 5652 & 7598 \\
\hline 12983 & 12128 \\
\hline 5828 & 7466 \\
\hline 24463 & 27192 \\
\hline$\$ 182511$ & $\$ 190611$ \\
\hline 85193 & 68345 \\
\hline $\begin{array}{r}9037 \\
69018\end{array}$ & $\begin{array}{l}11651 \\
5674\end{array}$ \\
\hline 78055 & 67725 \\
\hline 7138 & 620 \\
\hline 19195 & 19815 \\
\hline$\$ 12057$ & $\$ 19195$ \\
\hline
\end{tabular}

\section{Excess of total revenues over} non-salary expenditures

\section{Salaries}

Casual help

Office

Excess of total revenues over total expenditures for the year

Deficit - beginning of year

Deficit - end of year
826

096

484

2642

286 253

$\frac{814}{605}$

\section{8}

466

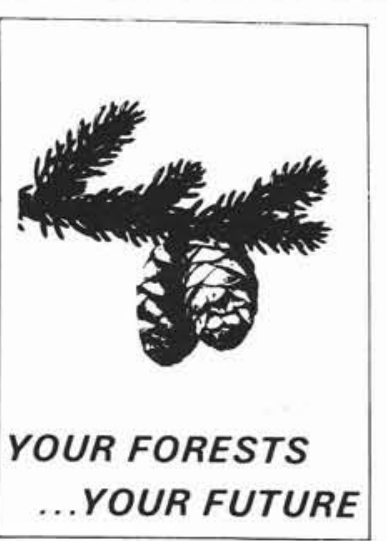

Notes to the Financial Statements, June 30, 1989

1. Significant accounting policy

Fixed assets

Purchases of office furniture and equipment are charged directly to expenditures. A nominal value of $\$ 1$ is carried on the balance sheet in recognition of the existence of such assets.

2. Other financial information

The Institute, incorporated Federally as a corporation without share capital, qualifies as a non-profit organization for an exemption from income tax under Federal and Ontario legislation.

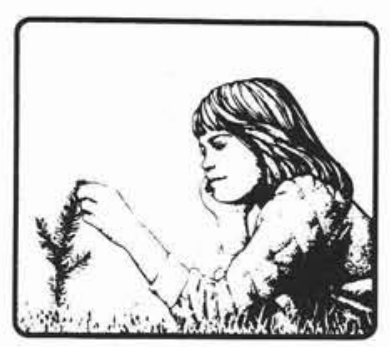




\section{Forestry Awareness in Canada Trust Committee (FACT)}

\section{8-89 Annual Report}

\section{Introduction}

1988-89 centered around the preparation and printing of the children's book "The Tale of the Forest of Havella land". This project consumed most of our available time. We did, however, review two requests for FACT seed money.

The FACT Board of Trustees have not changed since 1987. They are:

Glen Swant - President

Ernie Heidersdorf - Trustee

Jim Kayll - Trustee

Jim Cayford - Trustee and Secretary

\section{Activities}

The Tale of the Forest of Havella Land

On October 7, 1988, the Board authorized payment of $\$ 3300$ of FACT funds to Jon Williams to complete the layout, illustration, art work, and the type setting for the first copy. Then during the month of May 1989, we provided Mr. Williams with $\$ 1300$ so he could prepare six final copies for promotional purposes. If all goes well, I shall bring these copies to the 1989 national meeting.

Before we agreed to fund the final copies, Jim Kayll and myself thoroughly reviewed a draft of the text. In addition, a grade school teacher from Renfrew County School Board in eastern Ontario reviewed the text and provided comments.

The Ontario Ministry of Natural Resources are committed to 1500 copies of the book. So initial sales are good. The Canadian Forestry Association has also agreed to circulate and sell the book.

Our hope is that we can start publishing the first run of books by Christmas of this year and copies can be in the hands of school boards across the country by April 1990.

\section{Applications for Project Assistance}

We received two proposals. One was funded and the other was not.

The following is a brief description of the project which was approved for funding:
Title:
Section:
Herbicides and Forestry
Project Leader: Steve Talbot
Description of A publication in the form of a FACT booklet Project: designed to enhance the public's awareness of the use of herbicides in forest manage- ment practices. The booklet is set up in question and answer format and the pur- pose is to provide the necessary informa- tion so the public can make an intelligent decision. The publication has a Canada wide application.

FACT Funding

Received: $\quad \$ 1520.00$

\section{Summary}

At the EDUFOR' 89 meeting in Thunder Bay, I had the opportunity of explaining FACT and introducing "The Tale of the Forest of Havella Land" to educators and foresters from across the country. They liked and encouraged both. This is encouraging to all of us who work on FACT.

If we are to continue at the present level of forest management in Canada, we must inform the public and educate the future voters.

\section{Auditors' Report}

\section{To the Trustees of the Forestry Awareness In Canada Trust}

We have examined the balance sheet of the Forestry Awareness In Canada Trust as at June 30,1989 and the statement of operations and surplus for the year then ended. Our examination was made in accordance with generally accepted auditing standards and accordingly included such tests and other procedures as we considered necessary in the circumstances.

As is usually the case in organizations receiving donations, the verification of such items was impracticable beyond accounting for amounts recorded in the books of the organization.

In our opinion, except for the effect of adjustments, if any, which might have resulted had we been able to verify donations, these financial statements present fairly the financial position of the trust as at June 30,1989 and the results of its operations for the year then ended, in accordance with generally accepted accounting principles applied on a basis consistent with that of the preceding year.

OTTAWA, August 8, 1989

Cook, Perry, Sewell \& Co. Chartered Accountants

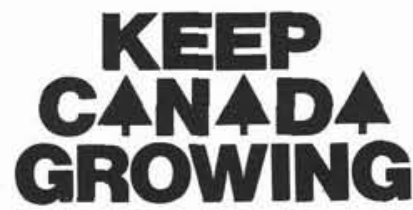


Forestry Awareness in Canada Trust Balance Sheet June 30,1989

\begin{tabular}{cr}
$\$ 4727$ & $\$ 1900$ \\
- & 8,595 \\
330 & \\
& $\$ 10511$ \\
\hline
\end{tabular}

\section{EQUITY}

Surplus $\stackrel{\$ 5057}{\underline{\$ 10511}}$

Forestry Awareness in Canada Trust Statement of Operations and Surplus for the year ended June 30, 1989

1989

1988

Revenues

Sales - books

Donations - members

Interest income

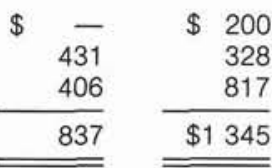

Expenditures

Special projects - sections $\quad 5570 \quad \$ 4250$

Miscellaneous

Decrease in inventory of books

\begin{tabular}{rrr}
5570 & & $\$ 4250$ \\
721 & & 737 \\
- & & 2145 \\
6291 & & 7132 \\
\hline 5454 & 5787 \\
10511 & 16298 \\
$\$ 5057$ & $\$ 10511$ \\
\hline \hline
\end{tabular}

\section{National Committees 1988/89}

\section{Membership Committee Report, 1988-89}

Actual membership figures for the CIF/IFC over the past six years are summarized in Table 1 . The figures are those immediately following the removal of members for nonpayment of dues. Membership has remained constant since 1985; between 1988 and 1989 there was a net loss of three members. However, it is evident that our percentage of potential members is declining; potential membership may be as high as 6000 .

Membership figures since 1987 have included all members of the Alberta Registered Professional Foresters Association persuant to an agreement with the organization. It should be noted that the numbers of their members, who have not joined the CIF/IFC has steadily declined from 129 in 1987 to 83 in 1989 (and to 68 by August 1989). Corresponding to this reduction is an increase in active members from 1578 in 1987 to 1711 in 1989 (and to 1781 by August 1989). Since the purge in February 1989 membership has increased by about $2 \%$ to 2393 .

The recruiting prize for $1988-89$ (Sept 1 , 1988 - August 31, 1989) was won by the Northwestern Ontario Section (Table 2). Other sections deserving honourable mention are Champlain, Cariboo and Orleans.

J.H. Cayford, R.P.F. Sept. 19, 1989

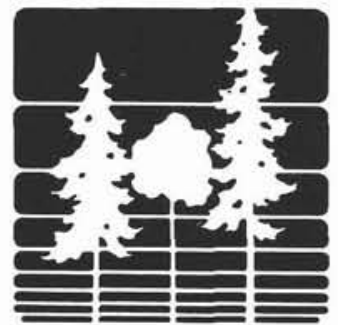

Table 1. CIF/IFC Membership, 1984 to 1989.

\begin{tabular}{lrrrrrr}
\hline Membership & $\mathbf{1 9 8 4}$ & $\mathbf{1 9 8 5}$ & $\mathbf{1 9 8 6}$ & $\mathbf{1 9 8 7}$ & $\mathbf{1 9 8 8}$ & $\mathbf{1 9 8 9}$ \\
\hline Active & - & 1842 & 1815 & 1578 & 1646 & 1711 \\
Affiliate & - & 87 & 75 & 54 & 66 & 65 \\
Fellow & - & 31 & 31 & 29 & 31 & 32 \\
Honorary & - & 4 & 6 & 6 & 6 & 5 \\
Retired paying & - & 112 & 119 & 136 & 147 & 161 \\
Retired non-paying & - & 116 & 116 & 110 & 116 & 126 \\
Students & - & 171 & 148 & 74 & 195 & 164 \\
Non-Members & - & - & - & 129 & 143 & 83 \\
\hline Total & 2435 & 2363 & 2310 & 2116 & 2350 & 2347 \\
\hline
\end{tabular}

Number of members following removal of members for non-payment of dues (January 1984, 1985, 1986, Mar 1987, 1988, Feb 1989). Non members are members of the Alberta Registered Professional Foresters Association and have not completed an application.

Table 2. Number of New Members by Section, September 1, 1988.

\begin{tabular}{lccc}
\hline Section code & $\begin{array}{c}\text { Number of } \\
\text { New Members }\end{array}$ & $\begin{array}{c}\text { Number of } \\
\text { Members }\end{array}$ & Percentage \\
\hline AL & 4 & 53 & 7.55 \\
CC & 1 & 25 & 4.00 \\
CR & 14 & 87 & 16.09 \\
CO & 13 & 124 & 10.48 \\
CH & 11 & 65 & 16.92 \\
LW & 4 & 45 & 8.89 \\
MB & 6 & 51 & 11.76 \\
MR & 21 & 181 & 11.60 \\
ND & 8 & 60 & 13.33 \\
NO & 2 & 24 & 8.33 \\
NW & 23 & 111 & 20.72 \\
NS & 10 & 111 & 0.01 \\
OK & 4 & 51 & 7.84 \\
OR & 15 & 95 & 15.79 \\
OV & 6 & 108 & 5.56 \\
PA & 3 & 36 & 8.33 \\
RM & 36 & 404 & 8.91 \\
SK & 5 & 49 & 10.20 \\
SN & 21 & 9.52 \\
SO & 2 & 165 & 4.85 \\
VA & 8 & 302 & 6.93 \\
VI & 30 & 177 & 6.78 \\
UN & 12 & 49 & 10.07 \\
\hline Total & 3 & 2394 & \\
\hline & 241 & &
\end{tabular}




\section{Report of the By-Laws Committee, 1989}

During the past year, the By-laws Committee received three requests from the Executive Committee to consider and propose changes to certain By-Laws of the Institute. The first asked us to propose new material that would cover the disbanding of defunct sections; the second, to phrase changes to the present by-law policy that would abolish the "non-paying" category of retired members; and the third, to revise the current membership by-laws to eliminate the "Affiliate Member" category.

The Committee's considered proposals for changes and new By-Laws to deal with these three matters were not developed completely until the third week of June. On June 21, our proposed text was sent to the Executive Director for Executive Committee consideration.

Pierre E. Zundel Arthur L. VanSlyke CIFIIFC By-Laws Committee

\section{Report of the Awards Committee 1988/89}

\section{Chairman: C. Godbout \\ Members: Executive Committee \\ Secretary: J.H. Cayford}

The Awards Committee is the Executive Committee sitting as a special committee of the whole. Recipients for the Canadian Forestry Achievement Award, the Canadian Forestry Scientific Achievement Award and the International Forestry Achievement Award were selected at the Executive Committee meeting. May 10-11, 1989. The Awards will be presented at the 1989 Annual Meeting. There have been no nominations for Honorary of Fellow Membership Status. The Awards Committee has selected one recipient for a special award. The Gold Medal winners at the universities were: U.B.C., Werner Stump; Alberta, Caroline Kutash; Laval, Julie Chagnon (Dec. 1988); Toronto, Dan Kneeshaw; Lakehead, Edward Henry Hoffman; and U.N.B., Edward Robert Wilson. The Schlich Award winner was Peter John Jofriet from U.N.B. In 1989, three members were admitted to the Golden Year Club A. Brookman Anderson, VA., A.H. Bamford, VI, and R.C. Telford, VA. Foresters rings were presented to approximately 250 graduating students - U.N.B. 36, Toronto 32, Lakehead 43, Alberta 32, U.B.C. 27, Laval 75. (December 1988). A final award is the membership award for the section obtaining the greatest percentage increase in membership.

\section{J.H. Cayford, R.P.F.} 1989.07.24

\section{Report of the Resolutions Committee for $1988 / 89$}

The number of resolutions received by the Committee was down somewhat from the preceding year. Three resolutions were received before the Annual General Meeting (in accordance with CIF/IFC directive); another 12 were received during the course of the meeting. Of these, one resolution was withdrawn and several were combined. Twelve resolutions were eventually presented to the membership during the final business session.

The quality of the resolutions submitted to the Committee was high and I commend the members for their thoughtfullness and consideration in bringing important issues forward. The Committee worked diligently with the proponents up to the last moment to bring well-worded and clear resolutions to the membership. I thank those involved for their co-operation.

Of the 12 resolutions presented to the membership, five were "external" resolutions (directing action to be addressed to target groups external to the CIF/IFC) and five were "internal" resolutions (directing action be taken within the CIF/IFC). One of these was withdrawn on the floor and one other was defeated. Two "standard" but important resolutions dealing with the ratification of the actions of the Executive Committee and the Board of Directors during the preceding year and with an expression of appreciation to HAMPCO ' 88 and the Saskatchewan Section for the holding of an excellent meeting were carried.

I wish to express my sincere thanks to Jim Richardson and Rene Doucet for their many hours of assistance in preparing the resolutions package. Without such help the presentation of the resolutions would not go ahead as smoothly as it has over the years.

L.F. Riley, R.P.F. Chairman

\section{Publication Policy Committee Report for 1988/89}

\section{Terms of reference}

1. To maintain a continuing review of existing CIF/IFC publications and publication policies.

2. To provide advice and guidance to the Editor of The Forestry Chronicle.

3. To carry out special assignments dealing with the CIF/IFC publications and publication policies as requested by the Executive Committee.

\section{Membership}

J.H. Smyth, D. Lockhart, P.E. Vezina, and J.H.G. Smith (Chairman)

\section{Accomplishments}

We continued to monitor The Forestry Chronicle and are satisfied with its contents and presentation. However, suggestions for improvement are always welcome.

The Executive Committee sought advice on names for replacing Drs. Redmond and Place when they retire, on whether or not the Editor and Production manager must reside in Ottawa, and what might still be done to further improve the Chronicle. A replacement is needed for Dr. Redmond as of the end of 1989 and $\mathrm{Dr}$. Place is planning to resign over the next two years. It seems best that replacements be sought in Ottawa, but the jobs could be done elsewhere at more expense by use of couriers.

The biggest challenge for members is to find means of attracting more and higher quality professional articles.

J. Harry G. Smith

\section{Archival Committee Report 1988-89}

The National Committee was unable to meet this year. However, Sections were contacted with suggestions for possible archival activities, including establishing contact with local historical societies and naming Section members interested in archival concerns. Such matters as collecting appropriate artifacts and interviewing those whose contribution to forestry is recognized but might otherwise be forgotten were proposed.

Those who established the Committee at the 1987 Annual Meeting realized that Section activities would be the measure of the Committee's effectiveness, and that activity would vary greatly from Section to Section depending on whether any members were keenly interested in the subject. Such has definitely been the case.

To keep abreast of archival activities, we suggest that Sections include reference to the topic in their annual reports. This would allow preparation of a national picture. An example of the importance of local committee action was the video-taping of an interview with Dr. J.W.B. Sisam by D.P. Drysdale of the Southern Ontario Section in July 1988 , which recorded the development of the Faculty of Forestry at Toronto from its inception in 1907. In January 1989 Dr. Sisam died, but much of the history of his works is now permanently recorded and is being used in the preparation of a brief biography of Dr. Sisam.

I am sure that possibilities exist in every Section to record and protect important archival information or material. This is a plea to Section chairpersons to provide an opportunity for Section members to discuss the topic and see whether a local program can be developed.

D.V. Love Chairman

\section{Report of Nominating Committee 1988-1989}

The Nominating Committee, composed of Peter Murphy (RM), Bob Spurway (MR), and Jim Kayll (Past President), reviewed possible nominees for the position of Second VicePresident and forwarded one name to the Executive Committee. Nominations closed without additional nominees.

\section{J. Kayll Chairman}

\section{Forest Science and Technology Board - Annual Report 1988-89}

The Forest Science and Technology Board (FSTB) was reconstituted at the 1988 Annual Meeting of the CIF/IFC and now consists of the chairpersons of the Institute's Working 
Groups. The Board elected Brian Haddon as Chairman and Brian Titus as Vice-Chairman and agreed to a program for the year during a teleconference in October 1988.

Four concurrent technical sessions were organized for the 1989 Annual Meeting by various Working Groups. Several CIF/IFC policy statements (brochures) have been or are being revised. A review of dormant and potential new Working Groups is ongoing. Recommendations regarding Working Groups will be submitted to the CIF/IFC Board of Directors. The annual meeting of the FSTB will be held in conjunction with the Annual Meeting of the Institute.

The FSTB has encouraged repetition of the very successful "Advances in Forest Research" symposium organized by the Algonquin Section in 1988. Central Ontario Section has taken up the challenge and plans to host a similar event in 1990 .

B.D. Haddon, R.P.F. Chairman

\section{Working Group Reports 1988-1989}

\section{Forest Ecology Working Group (A) - Annual Report 1988-1989}

The Working Group met in September 1988 at the CIF/ICF Annual Meeting in Prince Albert for a Joint Technical Session with the Silviculture and Tree Improvement, Forest Management, and Forest Economics and Policy Working Groups. The topic for the Session was "Managing for Aspen - A Shared Responsibility", and the Forest Ecology paper on "Ecosystems With Potential for Aspen Management" was presented by $\mathrm{Dr}$. Ian Corns. All four papers have now been published (For. Chron. 65: 16-35).

As indicated in a recent report on "Forest Science and Technology Board Revamped" (For. Chron. 64: 491), comments were made by some members of the WG on the ICF/IFC "Statement on Acid Rain".

Planning for the 1989 Annual Meeting in Kananaskis in October 1989 is virtually complete, and the WG will participate in a Joint Technical Session with Silviculture and Tree Improvement and Forest Pest Control Working Groups on the topic "Vegetation Management - Problem or Challenge?"'

Dr. Ian Corns (Forestry Canada, Northwest Region, Edmonton) is currently ViceChairman of the Working Group. Membership stood at 134 on 11 July 1989.

\section{Dr. B.D. Titus Chairman \\ 6 July, 1989}

\section{Economics and Policy Working Group (B) - Annual Report 1988-89}

The working group participated in a successful joint technical session with three other working groups at the 1988 CIF Annual Meeting in Prince Albert. The working group's contribution was a paper on the supply, demand, and policy issues for the use of aspen. The paper was presented by Jim Beck, and co-authored by Luis Constantino, Bill Phillips, and Mark Messmer, all from the University of Alberta. The working group also held an independent session on the implications of the Brundtland Commission Report on Canadian forest management. Main speakers were Dale Stewart, ADM Manitoba Dept. of Natural Resources, and Stan Rowe, University of Saskatchewan. All papers were published in the February, 1989 issue of The Forestry Chronicle.

A network of contacts was established across the country to facilitate the flow of information on policy developments to the Chronicle. These contacts represent every provincial government as well as the federal government in Ottawa. A substantial number of policy notes were published in 1988-89.

Linkages with the Canadian Association of Forest Economists (CAFE) were explored and an article on the 1988 Annual CAFE meeting was published in the Chronicle. This collaboration has led to several papers on forest economics and policy being published in the Chronicle and others submitted for publication. In addition, contact was established with the Forest Economics and Policy Analysis Unit (FEPA) at UBC. Subsequently, articles have been published in the Chronicle on FEPA activities, reports, and most recently, a paper on forest sector modelling.

Requests for assistance were received from the Executive Director. One concrete result was the completion of a Forestry Dialogue Forestier on the subject of trade in Canadian forest products.

For the 1989 CIF Annual Meeting in Kananaskis, a technical session has been organized jointly with the Forest Management Working Group. The topic is "The Potential for Integrated Resource Management with Intensive or Extensive Forest Management: Reconciling Vision with Reality". Participants will be F.L.C. Reed, C.A. Benson, I.D. Bird, B.P. Dancik, and R. Sedjo.

\section{Grant Milne} Chairman

\section{Forestry Education Working Group (C) - Annual Report/Newsletter $1988 / 89$}

One of the activities of the Working Group (W.G.) during the past year was the organization, with the kind cooperation of Forestry Canada and Walter Koch and others of the HAMPCO '88 Committee in Prince Albert, Sask., of a field trip to view private forestry activities in that province. The W.G. theme was "An overview of Private Forestry Developments in Saskatchewan" since the promotion of private land forestry and an intensive woodlot extension program are a relatively new endeavour thanks to the Canada-Saskatchewan Agreement (FRDA). An interesting field trip was arranged by Forestry Canada to see how the program is functioning on the ground with much better support than heretofore. A van-load of CIFIIFC delegates visited Frank Sudol of Paddockwood, Sask. Frank, at his impressive two-story log building, provided the opportunity to discuss the reasons for his management initiatives for the production of spruce and poplar sawtimber and firewood from his woodlot. With the growing need, as well as assistance available to private owners in eastern Canada, it was stimulating to see an example of what one dedicated and enthusiastic landowner can do to 'show the way' to other Prairie forest owners concerned with sustainable returns from their woodlots. The May 1989 Forestry Update reports the first meeting of the Sask. Farm Woodlot Association in April in Prince Albert.

The development of assistance to private forests and farm woodlots points up the need for Canadian schools of forestry to include regular courses on private forest management in their curricula. This should not be left to agriculture faculties. A resolution dealing with this matter was adopted at the business meeting which closed the CIF/IF annual general meeting (Res. 88.9).

\section{Comité Audet}

The undersigned, because of his CIF/IFC position as Chairman FEWG and long-time experience in private forestry, was invited by M. Albert Côté, ing.f., Ministre délégue aux forêts under the chairmanship of Jean Audet, MLA for Beauce-Nord to work, under contract, with four senior members of MER to review current systems and recommend new legislation for the effective management of private forests in Quebec. The mandate of the Comité was completed in late October 1988 , after seven months of intensive work involving weekly sessions, a four-day public audience and regional meetings throughout the province and the publication of an 84-page report; "La Forêt privée; Un Potentiel à Développer". The report contains 50 recommendations for the Ministry to ponder and act on. It is a very professional and thoughtful analysis on the direction Quebec private forestry should take in the near future. It should be required reading for foresters interested in the better management of farm woodlots and private forests who understand and present systems in use in Quebec, systems that encourage 'grass roots' involvement in managing an increasingly valuable and accessible resource.

\section{Correspondence}

In late 1988 the Executive Director forwarded a proposal prepared by Melissa Hadley RPF, intended for Science Culture Canada, to develop a video on the scientific and technological achievements of 
the Canadian forest sector, the consultant to work closely with the CIF/IFC Executive Committee and the FEWG. In the name of the WG, I fully supported this initiative. We hope that appropriate funding will be forthcoming for such a worthwhile educational proposal.

Kananaskis Symposium: Educating the Public-A Forestry Imperative

Finally, I would like to bring to your attention the upcoming Symposium organized by the FEWG, with the assistance of many individuals, to be held at Kananaskis on Thursday, Oct. 19, 1989 from 2:00-4:30 pm during the CIF/IFC AGM in Alberta.

It is essential that interesting and descriptive information about forestry reach the general public through as many avenues and as often as possible. The general public's understanding and awareness of forest technology, its importance to the nation and how it is practised is abysmal. All foresters can play a vital role in reaching the public through personal contact, the various media, through career days and information sessions and in other ways at every possible opportunity. The speakers at the FEWG session have all had considerable experience informing the public about forestry. They will tell us what must be done and how to do it.

\section{Symposium Panel of Speakers} $\begin{array}{ll}\text { W. Fullerton, R.P.F. Introducing Teachers } \\ \text { President, CFA } & \text { and Foresters }\end{array}$

G.Swant, R.P.F. Educating the Very President, FACT Young - A New Fairy Tale

Linda Moore, RPF. The Schools - A Vital COFI of B.C. Public

Paul Aird, RPF Univ. of Toronto

Conservation Education - Convincing or Confusing the Public

V. Brunette, ing.f. Reaching the Rural FPBQ, Chef Population - WoodMarches lots and Private Forests

Forum \& summary Comments and questions from members of the Working Groups

Summation:

Glen Blouin, R.P.F Executive Director. CFA

Working Group Business Meeting.

Looking forward to seeing you in Kananaskis.

Arch Jones, ing.f., Chairman

\section{Forest Pest Management Working Group (D) - Annual Report 1988-89}

During the year, Errol Caldwell succeeded Peter de Groot as chairman of the Working
Group. Although no meeting of the Working Group was held at the 1988 Annual Meeting, discussions took place with several other Working Group Chairmen to plan a joint Working Group meeting for the 1989 Annual Meeting.

The Forest Pest Control Working Group updated the CIF Policy on "Use of Chemical Pesticides in Forestry" in 1989. The title of the policy and its theme has been revised to the CIF Policy on "Integrated Forest Pest Management". The Working Group membership was solicited for comments and the final version of the policy statement should be available for distribution in mid-1989.

\section{Forest Hydrology Working Group (G) - Annual Report - 1989-90}

The Working Group met at the 1988 Annual Meeting in Saskatchewan. Only 8 people attended. D. Wilford (BC Forest Service) gave a paper on forest hydrology sensitivity analysis for coastal BC watersheds and P. Bernier (Forestry Canada) one on assessing water yield increases after logging. At the Kananaskis meeting in 1989, the WG will hold a panel discussion of hydrologic inputs to forest management. Pierre Bernier (Laurentian Forestry Centre, Forestry Canada) has volunteered to become the new chairman of the WG following the 1989 annual meeting.

\section{Forest Management Working Group (J) - Annual Report - 1988-89}

\section{Programs}

At the 1988 Annual Meeting, the Working Group participated in a joint session with the Ecology, Economics and Policy, and Silviculture and Tree Improvement Working Groups entitled "Managing for Aspen - A Shared Responsibility". Steve Smith, of Weyerhaeuser Canada Ltd. Prince Albert, Saskatchewan, gave the Forest Management Working Group paper "What Did you Expect?"

For the 1989 annual meeting, we have combined with Forest Policy and Economics to present five papers under the topic of "The Potential for Integrated Resource Management with Intensive or Extensive Forest Management: Reconciling Vision with Reality." G.R. Milne, Chairman of the Working Group will serve as Chairman of the session.

\section{CIF Brochure}

A draft revision of the CIF brochure, "How should Canada's Forest be Managed" was prepared.

\section{Membership}

In 1988 - 1989, 198 CIF members chose the Forest Management Working Group as their first choice.

\section{Executive}

On January 1989, C. Benson replaced Brian Hadden as Chairman for the working group.

C.A. Benson, R.P.F. Chairman, Forest Management 5 July, 1989
Silviculture and Tree Improvement Working Group (L) - Annual Report 1988-89

At the 1988 national Annual Meeting in Prince Albert, Saskatchewan, a joint technical session was held with three other working groups - Forest Ecology, Forest Management, and Forest Economics and Policy. Its theme was "Managing for Aspen - a shared responsibility." For the Working Group Dr. René Doucet, Ministère de l'Energie et des Ressources, Québec gave a paper entitled "Regeneration silviculture of aspen." The session papers were published in the February 1989 issue of The Forestry Chronicle.

A similar joint technical session is being organized for the 1989 national Annual Meeting in Kananaskis, Alberta. The Forest Ecology and Forest Pest Control Working Groups will join with the Silviculture and Tree Improvement Working group for a session on the theme "Vegetation Management Problem or Challenge?" This important and timely topic will be addressed from a variety of different perspectives by four speakers with knowledge and experience. Once again, the papers will be published in a future issue of The Forestry Chronicle.

This will be the fourth consecutive year in which such joint technical sessions have been the primary activity of the working group. They have been generally well received, and provide an opportunity for a broad national input to the technical program of the annual meeting. Subsequent publication of the papers presented permits all members to benefit.

A brief business meeting was held following the session in Prince Albert. At this meeting, the group's strategy was broadly endorsed, and the nomination of Dr. David Brand, Petawawa National Forestry Institute, Forestry Canada, as vice-chairman of the working group was confirmed. My own term of office began at the Prince Albert meeting and will run for two years.

\section{J. Richardson}

\section{Wildlife and Fish Habitat Working Group (N) - Annual Report 1988-89}

Members of the Wildlife and Fish Habitat Working Group have been involved in a variety of forestry-wildlife management and research activities. In New Brunswick, the Forest Habitat Project is integrating forest and wildlife management at a forest planning level. Wildlife habitat relationships are being modelled to assist in determining habitat supply. Wildlife habitat and forest inventories are used in a geographic information system to examine consequences of different forest management plans. In British Columbia, the Integrated Wildlife and Intensive Forestry Research Program is in its second phase and examining allocation of silvicultural treatments through space and time for the management of deer and elk in coastal forests. Several reports have been published on snow, forage and habitat selection. A 
'Handbook for Timber and Mule Deer Management' was published and is a guide for integrating habitat requirements of mule deer with forestry operations.

On the fisheries side, the long-term study of salmon and forestry at Carnation Creek, $\mathrm{BC}$ continues and a workshop reviewing the effects of herbicides on fish and their habitat was published in March 1989.

The working group membership stands at 22 for first choice and 26 for second choice. Members are from Newfoundland, Nova Scotia, New Brunswick, Quebec, Ontario, Saskatchewan, Alberta and British Columbia.

Alton S. Harestad

\section{International Forestry Working Group (O) - Annual Report 1988-89}

The CIF Annual Meeting held in Prince Albert, Saskatchewan, 1988, was both a success and a historical event for the IFWG. Mr. Ralph Roberts, Director of Forestry for CIDA was the recipient of the first International Forestry Outstanding Achievement Award, awarded by the CIF. The nameplate was in gold - all others to follow will be in bronze.

Bill Clarke, after serving as the IFWG secretary for a year, was reluctantly forced to resign due to heavy commitments to his job in Newfoundland. Bill received our warmest thanks for his dedication and a job well done. He has been replaced by Melissa Hadley of Vancouver, B.C.

Special thanks also go to Stan Pringle and Fred Johnson for their excellent and well received presentation on "International Trade and Improving Canada's Competitive Edge" to the IFWG at Hampco '88.

The IFWG vice president, Michel Laverdière spent much of 1988/89 in Kenya finishing his Ph.D. in agroforestry. $\mathrm{He}$ returned in mid March to resume his duties in Hull. Michel will, however, be returning to West Africa in late June for a 3-year posting with CIDA.

Three meetings were held by the IFWG during the year, one in Vancouver and two in Hull.

It was resolved that to maintain continuity, Michel Laverdière, would coordinate the preparation of a special International issue of The Forestry Chronicle, to be issued in time for the 1990 IUFRO Conference in Montreal. Melissa Hadley would coordinate the twinning of the CIF with the Chinese Society of Forestry

The IFWG thrust to support Professor FLC Reed's initiative to create the International
Centre of Excellence in Forestry at UBC has met with success. Initial emphasis will likely be on intelligence gathering and analysis with further expansion arising according to need. Dean R.W. Kennedy was very receptive to the concept and offered both support and valuable suggestions on how to proceed with creation of the centre. Professor Reed is finalizing the proposal for presentation and approval to the UBC Faculty of Forestry in September 1989.

The IFWG continues to solicit papers on International forestry activities from foresters working abroad, for publication in The Forestry Chronicle.

The IFWG meeting at Hampco ' 89 is now organized. The two main speakers, Richard Herring, Vice-president - Comptroller at CID and Dr. Jean Berard, President FERIC, will present papers on financial aspects of CIDA projects and on international technology transfer on forestry equipment, respectively.

Finally, Cameron Clarke's term as chairman of the IFWG will end at Hamco '89. Michel Laverdière will assume the chairmanship. Melissa Hadley will step up to vicechairman and a new secretary will be sought.

Cameron Clarke Chairman

\section{Report on the Canadian Journal of Forest Research}

The Canadian Journal of Forest Research is one of 13 journals published by the National Research Council. Now in its 19th year, the Journal continues to grow in popularity. In 1988, 429 manuscripts were received. So far in 1989, submissions are about equal to the same period in 1988 and close to double the number received five years ago. 198 Articles, 43 Notes, three Reviews, two Discussions and two Rapid Communications were published in 1670 pages and 12 issues in 1988 . We began publishing as a quarterly in 1971, went bi-monthly in 1983, and began publishing monthly in 1987. In the first eight issues published in 1989, 124 Articles, 34 Notes, one Review, and two Rapid Communications were published in 1076 pages.

About $35 \%$ of the manuscripts currently received originate from authors in Canada, $50 \%$ from those in the U.S. and $15 \%$ from scientists in other countries. Between 60 and $65 \%$ of the manuscripts received are published. On average, a manuscript is either accepted or rejected within five and a half months of receipt; this includes the time in the Associate Editor's and referees' hands, the time it takes the author to revise the manuscript, and any time necessary for review of the revised manuscript. Most manuscripts are returned to authors for revision (or rejected) within three months of their receipt. On average, a manuscript appears in print another five and a half months after acceptance

The Canadian Journal of Forest Research now ranks first among 13 forestry and forest products journals on the basis of the average frequency of citation for our articles by other papers (1987 SCl Journal Citation Reports). This continuing high ranking reflects the quality of manuscripts received and published and the Journal's international audience. With this high international reputation, the Canadian Journal of Forest Research expects to continue to attract the best manuscripts of the best Canadian and international scientists. In particular, we encourage the submission of manuscripts in novel and frontier areas of basic forest research so that we can continue to serve our readers in an increasingly competitive forestry journal market.

Total number of subscriptions remains below 1000 , which is still perplexing. In addition to the usual promotional activities to recruit new subscribers, we have been exchanging advertisements for the Journal with those of some of our competitors and with Forestry Abstracts. The regular appearance of our tables of contents in The Forestry Chronicle has kept the contents of the Journal before CIF members and hopefully will attract more subscribers at the special society rate.

The Journal's success is heavily dependent upon the volunteer efforts of many referees and the members of the Editorial Board. All of the referees and the 27 Associate Editors have our thanks for their excellent and tireless service.

Bruce P. Dancik Editor 


\title{
Canadian Institute of Forestry/Institut Forestier du Canada 81st Annual General Meeting October 16 and 19, 1989 Kananaskis Country, Alberta
}

\author{
MINUTES
}

\begin{abstract}
1.
Opening

President Godbout opened the meeting at 9:05 a.m.
\end{abstract}

\section{Deceased Members}

The President read the names of members deceased since the last Annual Meeting and asked delegates to stand and observe a moment of silence in their memory. They are:

Lionel Affleck Northwestern

Ontario

Frank A. Barkhouse Maritime Maurice Barteaux Maritime

Alan Beaven Manitoba (CFAA recipient 1985)

Lowell Besley

Garry E. Burghard Unclassified (President 1961; Fellow)

Richard Campbell Vancouver Section (Director)

W.B.G. Denyer

Ottawa Valley (former Editor Forestry Chronicle)

George Fahnestock Unclassified

W.E. Foster

E. Huestis

Ross Hyslop

Southern Ontario

Rocky Mountain

Southern Ontario

(50-year member

1988)

Ralph S. Johnson

Nova Scotia

(Fellow)

F. Malcolm Knapp Vancouver (Fellow)

J.A. Knuutinen

Northwestern

Ontario

M. Lortie

R.J. Lynn

H.A. Richmond

Jack M. Robinson

J.W.B. Sisam

J.A. Teasdale

P.E. Vezina

Ralph Carman

Orleans (CFAA

recipient 1986)

Unclassified

Vancouver Island (Fellow)

Ottawa Valley

Southern Ontario

(President 1955;

Fellow)

Algonquin Section

(50 year member 1980)

Orleans Section

(Chairman)

Southern Ontario

(former member)

3. Approval of Minutes of 80th Annual General Meeting

The minutes of the Annual General Meeting were published in The Forestry Chronicle, December 1988 issue.

MOTION G89-1 (H. Pratley, B. MacArthur)

THAT the minutes be approved.

Carried

4.

Officer's Reports

4.1 President's Report

The President presented his report. It will be published.

MOTION G89-2 (J.W. Toovey, D.R. Redmond)

THAT the report be accepted.

Carried

The President noted that L. Riley was Chairman of the Resolutions Committee and that J. Richardson and F. Sauvageau are members. Resolutions would be received until noon, October 18.

\subsection{Executive Director's Report}

The Executive Director summarized his report. It will be published.

MOTION G89-3 (J.R.M. Williams, R.M. Newnham)

THAT the report be accepted

Carried

4.3 Forestry Chronicle Editor's Report The Executive Director read the Editor's report. It will be published.

MOTION G89-4 (R. Strang, C.R. Silversides)

THAT the report be accepted.

Carried

4.4 Forestry Chronicle Production Manager's Report

The Production Manager, D.R. Redmond, summarized his report.

MOTION G89-5 (C. Harper, R. Doucet)

THAT the report be accepted.

Carried

\subsection{Report of Committees}

The Executive Director summarized reports of the Membership, By-Laws, Nominating, Resolutions, Awards, Publication Policy and Archival Committees. Reports will be published.

MOTION G89-6 (F. Sauvageau, H. Pratley) THAT the reports be accepted.

Carried

\section{Report of Chairman, Forest}

Science and Technology Board

The Chairman, B. Haddon, summarized his report. It will be published.

MOTION G89-7 (B. Titus, J.R.M. Williams) THAT the report be accepted.

Carried

\section{Report of President, Forestry}

Awareness in Canada Trust

Kayll summarized the report, prepared by

G. Swant. It will be published.

MOTION G89-8 (A.R.C. Jones, B. Haddon) THAT the report be accepted.

Carried

7. Presentation of Awards

7.1 Canadian Forestry Achievement Award C.H. Geale will receive the award at the banquet.

7.2 Canadian Forestry Scientific Achievement Award

F.C. Bunnell will receive the award at the banquet.

7.3 International Forestry Achievement Award

M. Stewart will receive the award at the banquet.

\subsection{Special Award}

Nova Scotia Section received a special award for its role in the St. Mary's River forestry/wildlife project. The award was presented to S. Hruszowy.

\subsection{Golden Year Certificates}

The members for 1989 are as follows: A. Brookman Anderson, A.H. Bamford, R.C. Telford. R.C. Telford was present to receive his certificate.

7.6 Membership Prize

The Section Membership Prize for obtaining the greatest percentage increase in membership was presented to the Northwestern Ontario Section. The prize was presented to M. Maley.

\subsection{Gold Medal Recipient}

Six Gold Medals were presented during the year to members of the graduation classes of the forestry faculties. Recipients were Julie Chagnon, Laval (Dec 1988); E.R. Wilson, UNB; Dan Kneeshaw, U of T; E.H. Hoffman, Lakehead; Caroline Kutash, Alberta; and W. Stump, UBC.

7.8 Schlich Memorial Prize

The recipient was Peter John Jofriet, UNB.

\subsection{Rings}

During the year, the CIF/IFC presented rings to 245 graduating forestry students at six forestry facilities.

President Godbout acknowledged the presence of Past Presidents Kayll, Toovey, Cayford, Garner, Smith, Redmond, Love and Hearnden.

8.

Finances

8.1 Finance Committee Report

J.H. Cayford summarized the Finance Committee report. It will be published. MOTION G89-9 (J.H. Cayford, R. Stoddart) THAT the report be accepted.

Carried

8.2 Auditor's Report

J.H. Cayford summarized the Auditor's report. It will be published.

MOTION G89-10 (J.H. Cayford, D. Couch) THAT the report be accepted.

Carried

8.3 Budget, 1989-90

J.H. Cayford discussed the budget. It will be published. 
MOTION G89-11 (J.H. Cayford, B. Murphy) THAT the budget be approved.

8.4 Appointment of Auditor

MOTION G89-12 (J.H. Cayford, V. Heath)

THAT Cook, Perry, Sewell and Co. be appointed as auditors for CIF/IFC for 1989-90 provided that satisfactory arrangements can be made and failing that the Executive Committee make other arrangements.

Carried

\section{Membership Action Plan}

C.H. Gairns reviewed the development and status of the Membership Action Plan, discussing in particular the proposal to eliminate Affiliate membership category, the proposed dues structure, the membership drive and and active program to retain members

\section{Three-Year Plan 1989-91}

P. Ackhurst presented a three-year plan, 1989-91, prepared at the Board of Directors Meeting, which included items dealing with FACT fund, Forest Science and Technology Board, HAMPCO, Forestry Chronicle, Banner Issue - Sustainable Development, Search Committee. Membership Drive and FRDA II. The plan is attached as Appendix I.

\section{By-Laws and Rules and Regulations} 11.1 By-Laws 3.2 Active Members

MOTION G89-13 (B. MacArthur, M. Clark)

THAT By-Law 3.2 be amended as follows:

\subsection{Active Members}

3.2.1 Regular qualification: Upon recommendation by a Section Council or a member of the Executive Committee and approval by the Executive Committee. Active Member status shall be granted to persons who, through post-secondary training and education, have earned a certificate, a diploma or a degree in forestry (including forest engineering; wildlife; wood science), in forestry-related science or applied science, or in other pertinent science and social science programmes. Such programmes may include business administration, agriculture, climate and weather, communications, economics, geography, public relations, sociology, and possibly others that may be identified from time to time by the Board of Directors

3.2.2 Other qualification: Upon recommendation by a Section Council or a member of the Executive Committee and approval by the Board of Examiners, Active Member status will be available to persons who hold responsible forestry or forest-related positions, or who have been engaged in forestry or forestrelated practice for five years, or who, having expressed interest in forestry, are considered to have the potential to advance sound forestry practices.

MOTION to amend (R.M. Strang, G. Frisque)

THAT the words approved be inserted before certificate.

Defeated: 5 in favour 62 opposed 3 abstentions

MOTION to amend (T. Sifton, G. Young)

THAT Section 3.2.1 be terminated after forestry-related science.
Defeated: 12 in favour 58 opposed 4 abstentions MOTION to amend (J.H.G. Smith, R. Swanson)

THAT the words recreation, range and watershed management be inserted after wood science.

Carried: 44 in favour 23 against 4 abstentions

Vote on amended By-Law.

$$
\begin{array}{r}
\text { Carried: } 58 \text { in favour } \\
16 \text { against } \\
4 \text { abstentions }
\end{array}
$$

\subsection{By-Laws 3.3 Retired Members}

MOTION G89-14 (C. Harper, T. Sifton)

THAT By-Law 3.3 be amended as follows:

3.3 Retired Members

Upon recommendation by a Section Council or a member of the Executive Committee and approval by the Executive Committee, Retired Member status shall be granted to persons who have been Institute members for fifteen or more years, but who are now retired from full-time employment and receiving a much-reduced income.

\section{Carried: 73 in favour 3 abstentions}

\subsection{By-Laws 4.4 and 4.5}

MOTION G89-15 (G. Aubin, B. Murphy)

THAT By-Law 4.4, Retirement, and By-Law 4.5, Applications without Section Affiliation, be deleted.

Carried: Unanimously

\subsection{By-Law 9.2.2 Voting Rights}

MOTION G89-16 (C.H. Gairns, M. Clark)

THAT By-Law 9.2 .2 be amended as follows: 9.2.2 Voting Rights. Only Active and Retired members may vote in the affairs of the Institute. Each Active and Retired member present at a general meeting shall have the right to exercise one vote except that an Active or Retired member may appoint, in writing, any other Active or Retired member present at the meeting to vote as proxy.

Carried: one abstention

11.5 By-Law 13.8, Disbandment of an "Inactive Section"'

MOTION G89-17 (B. Murphy, C. Harper)

THAT a new By-Law 13.8 be approved.

13.8 Disbandment of an "Inactive" Section 13.8.1 Disbandment: A Section which has held no meetings for two years, or has not otherwise participated in Institute affairs, may be deemed by the Board of Directors to be inactive. In such cases, if the Board decides to initiate a disbandment process they shall provide the membership of that inactive Section with advance notice of their intent. That notice shall specify a period during which members may challenge the decision, and the manner by which the members could show cause why the disbandment should not occur.

13.8.2 Report to Members: The Board of Directors shall communicate to the members of a disbanded Section such closing details as the Board considers pertinent, including explanation about the disposition of any Section assets/liabilities, and suggestions about alternative Section membership opportunities.

Carried: Unanimously

11.6 Rule and Regulation 4.3.7, Tree of Life Award

MOTION G89-18 (C. Harper, R. Stoddart)

THAT a new rule and regulation 4.3 .7 be approved.

4.3.7 Tree of Life Award: Each year on or before May 1, Section Councils and the Executive Committee may name recipients to a Tree of Life Award.

The number of awards presented annually will normally not be more than $1.0 \%$ of the CIF/IFC membership and will be coordinated by the Executive Director.

Carried: 1 opposed

12. National Dues 1990-91

A proposal for national dues for 1990-91 was presented.

MOTION G89-19 (C. Harper, J.R.M. Williams)

THAT the dues for $1990-91$ be set as follows:

\section{CIF/IFC DUES 1990-1991}

\section{Active Membership}

1 st and 2 nd year after gradua-

tion (grad 1989, grad 1988)

Other new members for first

year

Married or equivalent, second

member only

All other active members

\section{Other Memberships}

Members having retired status, prior to 1990-91 who wish to

receive the Forestry Chronicle

Members having retired status,

prior to 1990-91, who do not

wish to receive the Forestry

Chronicle

Members granted retirement

status subsequent to $1989-90$

Student Members

Sustaining Individuals (CIF

Members)

Sustaining Corporate

\section{Forestry Chronicle Subscription} Rates - 1991

A proposal for 1991 Forestry Chronicle subscription rates was presented by J.H. Cayford.

MOTION G89-20 (J.H. Cayford, D.R. Redmond)

THAT the 1991 Forestry Chronicle subscription rates be as follows:

\section{Inside Canada}

Libraries and other multi-users

Single user

$\$ 75.00$

$\$ 68.00$

\section{Outside Canada}

Libraries and other multi-users Single user

\section{Price of Single Issues}

- Not more than two years old

$1 / 5$ of annual subscription rate

- More than two years old

$\$ 18.00$ 
14.

\section{Staffing}

The President announced the appointment by the Board of Directors of Dr. I.C.M. Place, as Editor of The Forestry Chronicle and T. Fenton, as Production Manager of The Forestry Chronicle, for calendar year 1990.

15.

Future Meetings

The President reported that the locations of Annual Meetings have been approved as follows:

1994- Pacific Northwest, joint meeting with S.A.F.

1993 - Montreal

1992 - Vancouver

1991 - Toronto

1990- Fredericton

16.

\section{Resolutions}

L.F. Riley, Chairman of the Resolutions Committee, outlined the procedure for considering resolutions and chaired the meeting during their presentation.

Resolution 89.1 (P. Aird, SO, A.R.C. Jones, $\mathrm{CH})$

WHEREAS The conservation of the world's biological diversity requires the effort of Canadians at the local, national and international levels; and

WHEREAS The loss of biological diversity includes not just the extinction of species, but also significant reduction in natural habitats, and in abundance, range, or genetic variation of wild plant and animal species, often caused by human intervention; therefore

BE IT RESOLVED that the CIF/IFC ask the Minister, Forestry Canada, to facilitate the preparation of an overview report on the current federal and provincial policies, practices, scientific research and planning with respect to the conservation of biological diversity in Canadian forests: and

BE IT FURTHER RESOLVED that the CIF/IFC ask the Minister, Forestry Canada to assist in the development of plans for appropriate action to sustain and enhance the biological diversity of Canada's forestbased wild plants and animals in their natural habitats.

Carried: 3 opposed 1 abstention

Résolution 89.2 (B. Coté CH, F. Sauvageau $\mathrm{CH})$

Etant donné que le phénomène des pluies acides et de la pollution atmosphérique n'est pas un phénomène temporaire et localisé; et

Etant donné que les gouvernements ont mis en place un programme de lutte contre le dépérissement des érablières et que les budgets alloués sont insuffisants puisque répondant à seulement une fraction de la demande de la première année d'application; et

Etant donné que le phénomène du dépérissement affecte un nombre toujours croissant d'essences commerciales et de peuplements forestiers; et

Etant donné que la fertilisation est une mesure palliative passagère permettant de réduire les pertes en attendant d'agir sur la ou les causes de dépérissement; et

Etant donné que le dépérissement des écosystèmes forestiers entraîne d'impor- tantes pertes économiques et menace notre milieu de vie; en conséquence

II est résolu que le CIF/IFC demande au gouvernement fédéral:

(1) D'allouer des budgets additionnels pour permettre de poursuivre l'effort de recherche sur le phénomène du dépérissement des forêts au-delà des trois années initialement prévues dans l'entente fédérale-provinciale de lutte au dépérissement des érablières au Québec, et

(2) D'augmenter les budgets alloués au programme de lutte contre le dépérissement des écosystèmes forestiers, et

(3) D'étendre les budgets de lutte contre le dépérissement à toutes les régions affectées et de les rendre accessibles à tous les producteurs forestiers, et

(4) D'intervenir pour éliminer à la source la pollution atmosphérique tant au Canada qu'aux États-Unis.

\section{Resolution $\mathbf{8 9 . 2}$}

BE IT RESOLVED that the CIF/IFC ask the federal government to

(1) allocate additional funds in support of research on forest dieback phenomena beyond the initial three years of the federalprovincial agreement on control of maple dieback in Quebec.

(2) increase the allocation of funds to the control program on forest ecosystem dieback.

(3) extend the dieback program to all affected regions and make it available to all forest owners, and

(4) act to eliminate at source atmospheric pollution in Canada as well as in the United States.

Carried: 3 opposed 1 abstention

Résolution 89.3 (J.-M. Lacasse CH, F. Sauvageau $\mathrm{CH}$ )

Etant donné que les Ententes fédéralesprovinciales de mise en valeur de la ressource forestière (EMVRF) des provinces de la Nouvelle-Ecosse, du Nouveau-Brunswick, de I'Ontario, du Manitoba, de la Saskatchewan et de l'Alberta ne sont toujours pas renouvelées; et

Etant donné que les EMVRF des provinces de Terre-Neuve, Québec et ColombieBritannique expireront au 31 mars 1990; et

Etant donné qu'une part importante de ce financement est consacré aux domaines autres que la sylviculture tel que la recherche forestière, le transfert technologique, la recherche de nouvelles utilisations et les autres activités d'aménagement forestier; et

Etant donné que le patrimoine forestier canadien doit être sauvegardé pour la jouissance de nos enfants et des générations futures; et

Etant donné qu'avec la création du Ministère des Forêts, le gouvernement fédéral reconnaît l'importance d'assurer la pérennité de la ressource forestière; en conséquence:

Il est résolu que les sections régionales du CIF/IFC continuent d'informer et de sensibiliser, par leurs activités, leurs membres et les non-membres de l'importance du renouvellement de ces ententes, et que
Le CIF/IFC exerce les pressions nécessaires afin d'accelérer le processus de renouvellement des ententes fédéralesprovinciales de mise en valeur de la ressource forestière, et que

Le CIF/IFC poursuive ses pressions auprès du gouvernement fédéral pour,

(1) Signer, avant la fin de 1990, de nouvelles ententes fédérales sur la mise en valeur de la resource forestière pour toutes les provinces, et

(2) Etablir des objectifs de mise en valeur en fonction des besoins et de déterminer les moyens pour atteindre ces objectifs et ce, en collaboration avec l'ensemble des intervenants impliqués, et

(3) Augmenter les investissements à 1.5 milliard de dollars, et

(4) Fixer ces ententes pour une période minimale de cinq ans, et

(5) Prévoir des fonds pour l'inventaire forestier, la classification des terres, l'aménagement polyvalent, la recherche forestière, le transfert technologique, la sensibilisation du public et toute autre activité susceptible de maintenir la ressource forestière en terme de quantité et de qualité.

\section{Resolution 89.3}

BE IT RESOLVED that the CIF/IFC sections, through their activities, continue to inform members and non-members alike and make them aware of the importance of renewing the federal-provincial forestry agreements, and

BE IT FURTHER RESOLVED that the CIF/IFC exert pressure as needed in order to speed up the renewal process, and

BE IT FURTHER RESOLVED that the CIF/IFC exert pressure on the federal government to:

(1) sign new federal-provincial forest resource development agreements with all provinces before the end of 1990, and

(2) establish the goals for the agreements in terms of the needs and identify the means of reaching these goals in collaboration with all concerned parties, and

(3) increase the allocation of funds to 1.5 billion dollars, and

(4) fix the duration of the agreements at a minimum of five years, and

(5) make funds available for forest industry, land classification, multiple use management, forest research, technology transfer, public awareness and any other activity required to maintain the forest resource in terms of quantity and quality.

Carried: 1 abstention

Resolution 89.4 (R.M. Strang VA, A.R.C. Jones $\mathrm{CH}$ )

WHEREAS it is desirable to enhance the profile of the CIF/IFC as a responsible "voice" for forestry; and

WHEREAS graduates of the forestry diploma programmes from Canada's colleges and institutes constitute a large pool of potential members; and

WHEREAS this pool is a valuable and underutilized resource; therefore

BE IT RESOLVED that the executive, and the membership, of the CIF/IFC pay more attention to technical forestry colleges than 
they now do and, specifically consider awarding gold medals annually to the most deserving graduates from the nation's forestry colleges and institutes.

Carried: 2 opposed

1 abstention

Resolution 89.5 (J.A.F. Gardner VA, R.J. Bourchier OV)

WHEREAS Dr. Douglas Redmond has been very active in CIF/IFC affairs over the years bringing unflagging enthusiasm to roles as varied as National President and acting Executive Director; and

WHEREAS The Forestry Chronicle has shown steady improvement in appearance, layout and readability; and

WHEREAS Dr. Redmond has been in charge of production of The Forestry Chronicle over the past four years; therefore

BE IT RESOLVED that the CIF/IFC express its sincere gratitude and appreciation to Doug Redmond for his valuable work on The Forestry Chronicle and his sustained contribution to institute goals and objectives.

Carried

Resolution 89.6 (W. Wellburn VA, D.V. Myles OV)

WHEREAS the world is facing environmental and pollution problems which will seriously affect life in the future; and

WHEREAS many environmental and pollution problems are attributed to forestry and forest products manufacturing; and

WHEREAS large amounts of money will have to be spent worldwide to solve these problems and reduce the consequences; and

WHEREAS this money will have to be provided by the developed countries, including Canada; and

WHEREAS it is essential that this money be spent wisely on real rather than perceived problems; therefore

BE IT RESOLVED that the CIF/IFC urge the Canadian Council of Resource and Environment Ministers (CCREM) and the Canadian
Council of Forest Ministers (CCFM) to petition the United Nations to establish a followup to the Brundtland Commission for the development of world protocols for dealing with environmental problems and of methods to measure and monitor the causes and effects of identified problems as well as the results of corrective actions.

Carried

Resolution 89.7 (A.R.C. Jones CH, D.V. Love SO)

WHEREAS the working groups of the CIFIIFC are an important mechanism for member involvement in the organization as well as a means of focussing on elements of forestry important to the membership; and

WHEREAS deliberations of working groups at Annual General Meetings of the CIF/IFC provide one of the best sources of considered opinion at an Annual Meeting; and

WHEREAS ideas expressed at the working group meetings should be brought before the membership prior to the passage of resolutions; therefore

BE IT RESOLVED that working group technical sessions at Annual General Meetings of the CIF/IFC be held at a time during the program such that resolutions emanating from these sessions can be presented to the general membership for ratification.

Carried: 5 abstentions

\section{Resolution 89.8 (J.W. Ebbs SO, M. Summers} RM)

WHEREAS The National Executive of the CIF/IFC has acted on behalf of the combined membership over the past year; therefore

BE IT RESOLVED that the members of the CIF/IFC at the 81st Annual General Meeting ratify, sanction and confirm all acts, covenants and proceedings made, taken or entered into on their behalf by the Board of Directors and by the Executive Committee during the past year.

Carried
Resolution 89.9 (W.K. Fullerton SO, G. Frisque $O R$ )

WHEREAS The 1989 Annual General Meeting has enabled those members participating to view with greater clarity the differences between vision and reality with respect to forest management and related disciplines, has aided us in working towards a reconciliation of the two, has provided a variety of interesting field trips and has promoted congeniality and social interaction to the highest extent possible; therefore

BE IT RESOLVED that the delegates to this meeting applaud and heartily thank the members of Rocky Mountain Section and HAMPCO'89 for planning and conducting a meeting that has been both intellectually rewarding and socially unsurpassed in spectacular Kananaskis Country in the province of Alberta.

Carried

17.

\section{Other Business}

17.1 IUFRO World Congress

L.F. Riley briefly discussed the IUFRO World Congress scheduled for Montreal, August 1990.

\subsection{Annual Meeting}

T. Sifton outlined plans for the 1990 Annual Meeting to be held in Fredericton, August 1990

18.

New Officers

President Godbout introduced the new officers for 1989-90 and thanked Past President A.J. Kayll for his contribution. He welcomed A. Whidden as Second VicePresident, C.H. Gairns as First Vice-President and $P$. Ackhurst as President and passed the gavel to $P$. Ackhurst.

$19 . \quad$ Adjournment

President Ackhurst adjourned the 81st Annual Meeting at 11:30 hours

J.H. Cayford, R.P.F. Executive Director October 29, 1989

\section{APPENDIX I CIFIFC Three Year Plan - 1989-1991 Director's Meeting October 13 \& 14, 1989 Kananaskis, Alberta}

1. Fact Fund

2. FSTB

3. HAMPCO

4. Forestry Chronicle

5. Banner Issue-Sustainable

Development

6. Executive Director \& Editor

7. Membership Drive

8. FRDA II

\section{FACT}

- Executive Committee will review and recommend further action.

- Sections identify major projects.

- Promote.

\section{FSTB}

a) Executive to ask Working Groups to identify actions.

b) FSTB to promote activities and solicit feedback.
HAMPCO

Rewrite and distribute revised manual to future HAMPCO Committee.

\section{Forestry Chronicle}

Implement the recommended changes.

Banner Issue - Sustainable Development

- CIF position paper - FSTB - Jan.'90.

- Link to, and participate in other sustainable development conferences.

- Chronicle article - Feb.'90.

- Focus on round tables - National - Exec.

- Provincial - Sections

- Form Executive Committee to coordinate actions.

- Attend CCFM Workshop - Feb'90, Halifax
Search Committee

a) Executive Director

b) Editor

Membership Drive

- Membership drive - Sections - Feb.'90

- Status quo fee structure.

- Eliminate affiliate category.

- Feedback form on Section membership.

- Revise membership award.

FRDA I

- Promote.

- One more letter

Others

- Increase other revenue.

- IUFRO.

- Forestry Awareness Project.

- Communicators Forum - 1991

- Research Forum - Oct'90, Sault Ste. Marie. 


\section{Executive Committee Meets With Federal and Alberta Ministers}

On the occasion of the 1989 Annual Meeting, the Executive Committee met with the Hon. Frank Oberle, Minister of State (Forestry), Canada, and with the Hon. Leroy Fjordbotten, Minister of Energy and Resources, Alberta. These meetings maintained current practice whereby the Executive Committee meets twice annually with the federal minister responsible for forestry and meets with provincial ministers on the occa- sion of the annual meeting. Both meetings were also attended by Brian MacDonald, Chairman, Rocky Mountain Section.

The meeting with $\mathrm{Mr}$. Oberle included discussion of the Department of Forestry Act, Forest Resource Development Agreements, CIF/IFC linkages and initiatives with Forestry Canada and the Canadian Council of Forest Ministers and with the Forest Sector Advisory Committee.

\section{Section Reports}

\section{Report to CIF Board of Directors, October 14, 1989}

After many distressing delays and setbacks, preparations are now under way for the 1991 Annual General Meeting, to be in Toronto. It will be earlier than previously announced, the week starting Sunday, September 22, 1991. It will be at Inn on the Park, at Eglinton Ave. and Leslie St. in the northeastern part of Metro Toronto. It has the required facilities, including up to 450 guest rooms. Also there is the possibility of access to facilities at the Ontario Science Centre, a short walk away.

Many CIF members coming to Toronto will doubtless want to go downtown. We chose Inn on the Park partly because it will be less costly to delegates than downtown locations, and partly because of convenience to anyone coming by car; we expect to arrange transport to and from both the airport and downtown (e.g. to a subway station).

It was suggested I bring you tourist literature telling you all about the tremedously exciting things to see and do in Toronto. Instead I'd like to have a word about why we want you to come to a CIF meeting in Toronto. (You can get tourist literature from Metro Toronto Convention and Visitors Association, Box 126, 207 Queen's Quay W., Toronto, Ont. M5J 1A7). We have tentatively chosen a Meeting theme FORESTRY FOR PEOPLE, not unlike that of the 1974 meeting, the last one to be held in Southern Ontario.

Forestry for People? We have people! Over a quarter of the Canadian population, i.e. a quarter of taxpayers and voters, live in the Southern Ontario Section. Most of us are urban. We're an increasingly diverse lot. UN has declared Toronto the most ethnically diverse city in the world.

We have urban forestry programs, and probably could use more. Street trees in the City of Toronto are inventoried, the land base put in compartments, and management plans prepared, all with some striking parallels to the processes on Crown lands, more familiar to most members. Forest management is beginning in ravines, cemetaries, and elsewhere. (Inn on the Park overlooks a forested bit of ravine.) North York is re-creating wilderness areas in its parks, an activity recently noted in Canadian Geographic. The Don River, now one of the dirtiest in the country, and its ravine, partly wooded, will get a billion dollar cleanup. Vigorous debate centres on the preservation of the Rouge Valley. And so it goes.

But what has this forest to do with the vast forest that covers half of Canada's land area? This is the forest seen every day by the bulk of Canadians, citizens, taxpayers, voters, and their elected representatives. It is the forest that will help most of us be aware of the larger forest that covers half of Canada. It affects our asthetic, psychological, and yes, economic well-being. (Economics? the 60 -year-old tree on my lawn is likely the biggest reason I don't need an air-conditioner. Psychology? Hospital patients are known to get better faster and with less medication if they can see tree(s) than if they can't.)

Moving out of the city, we have heard much recently about agroforestry in the third world, and in the USA. Well, let me tell you that its coming here too. We have a major concentration of highly productive agricultural land, within which is a forestry component that is evidently suffering from decades of neglect. At least two agricultural schools in southwestern Ontario have agroforestry research programs. Intercropping, streamside plantings, land rehabilitation, windbreaks, etc. are receiving at least experimental attention. You will see this.
Topic discussed with $\mathrm{Mr}$. Fjordbotten included the role of the CIFIFC, renewal of federal-provincial forest resource development agreements, sustainable development, strategic planning, public awareness and CIF/IFC interactions with the Canadian Council of Forest Ministers.

\section{J.H. Cayford, R.P.F.} Executive Director
The natural forest of Southern Ontario is mainly tolerant hardwood. We have roughly a third of Canada's woodlots, a resource with enormous potential for economic, recreational and environmental benefits, if their extent and condition can be restored. We can show you some forestry success stories to show what can be done.

So we have forest; we have people: most live in the cities. And we have the elected representatives of those people: 99 of Ontario's 135 provincial members; 73 MPs, and over $60 \%$ of Ontario's organized municipalities and therefore literally thousands of municipal politicians. It is distressing to see them daily in thousands, e.g. in the subway, and wonder what proportion of them have a clue of how important Canada's forest resource is to each one of them, why we in forestry have never bothered to tell them, yet how their votes will profoundly influence forestry's future.

Too slowly, perhaps, both in and outside the forestry community, steps are being taken to raise the awareness of these people and, more importantly, of young people. We plan to tell you something about this too. The CIF co-hosted a communicators' forum last March in Toronto to come to grips with this challenge.

More and more interest groups are directing their attention to Canada's forests. Many of these are headquarters in the Toronto area, and we will increasingly be seeking dialogue with them.

There is this and much more. We invite CIF members everywhere to set aside the week of September 22, 1991, to come see Toronto, stay at INN on the PARK, and enjoy a week of Forestry.

J.R.M. (Mack) Williams Director, Southern Ontario Section October 14, 1989 